\title{
Milk Protein Synthesis as a Function of Amino Acid Supply*
}

\author{
L. Doepel, ${ }^{1,2} †$ D. Pacheco, ${ }^{2,} \ddagger$ J. J. Kennelly, ${ }^{1}$ M. D. Hanigan, ${ }^{3}$ \\ I. F. López, ${ }^{4}$ and H. Lapierre ${ }^{2}$ \\ ${ }^{1}$ Department of Agricultural, Food and Nutritional Science \\ University of Alberta, Edmonton T6G 2P5 \\ ${ }^{2}$ Dairy and Swine Research and Development Centre \\ Agriculture and Agri-Food Canada, Lennoxville, QC, J1M $1 Z 3$ \\ ${ }^{3}$ Purina Mills Inc. \\ St. Louis, MO 63166-6812 \\ ${ }^{4}$ Instituto de Producción Animal \\ Universidad Austral de Chile, Valdivia, Chile
}

\begin{abstract}
Most prediction schemes of milk protein secretion overestimate milk protein yield from dairy cows at high protein intakes, thereby overestimating milk protein yield response to protein supplementation. This study was conducted to determine factors contributing to such an overestimation. Using published studies, a database was constructed that was limited to amino acid (AA) infusion studies, as then only the digestible amino acid of dietary origin needed to be estimated, whereas the amount infused was known exactly, thereby reducing the dependence on estimated values.
\end{abstract}

Although milk protein yield was positively related with total energy supply, and both digestible duodenal supply and infused AA, in this database there was no relationship between milk protein yield response above control treatments and the nutrient status of the cows (energy or protein). Total milk protein yield was defined as a function of individual AA supply, using a segmented-linear and a logistic model to obtain estimates of the efficiency of conversion of AA into milk protein. Except for Lys and Met supply, the segmented-linear model yielded lower root mean square error and better correlation, but both models were similar in their reliability. For both models, the estimated efficiency of conversion of AA to milk differed among AA. Estimations of the ideal profile of AA for lactating dairy cows were similar between models, with requirements for Lys and Met in line with 2001 National Research Council recom-

Received March 17, 2003.

Accepted September 5, 2003.

Corresponding author: H. Lapierre; e-mail: lapierreh@agr.gc.ca.

*Lennoxville Research Centre contribution number: 816; this work was partly supported by a grant from the Dairy Farmers of Canada.

$\dagger$ Recipient of a scholarship granted by the Natural Sciences and Engineering Research Council of Canada.

$\ddagger$ Current address: AgResearch Ltd., Private Bag 11008, Palmerston North, New-Zealand; the contribution of the second author is equivalent to the contribution of the first author. mendations. The major difference is that the segmented-linear model yields a constant efficiency of conversion of an AA until requirements are met, with zero efficiency beyond this point. The logistic model allows for an estimation of the decreasing marginal efficiency of conversion of AA as the supply approaches the requirements. The use of variable efficiency factors should improve our ability to predict protein yield in response to supplemental protein.

(Key words: amino acid, requirement, lactation, efficiency)

Abbreviation key: AAT = total digestible AA from diet and infusion, CPT = total CP supply from diet and infusion, EAA = essential AA, MP = metabolizable protein, $\mathbf{M P T}=$ total MP supply from diet and infusion, NEAA = nonessential AA, NELT = total $\mathrm{NE}_{\mathrm{L}}$ supply from diet and infusion, $\mathbf{P D I}=$ protein truly digested in the small intestine, $\mathbf{P Y}=$ milk true protein yield; $\mathbf{P Y} \boldsymbol{\Delta}=$ milk protein response; $\mathbf{R M S E}=$ root mean square error .

\section{INTRODUCTION}

With current milk pricing strategies in Canada and the United States, profit margins for producers can often be improved by maximizing milk protein yield (PY). However, increasing milk protein content by nutritional manipulation is difficult (DePeters and Cant, 1992). Increasing the supply of RUP does not ensure improved milk protein production (Santos et al., 1998). Substitution of RDP by RUP can lead to decreased microbial protein synthesis and therefore does not necessarily result in overall positive effects on the amount and profile of AA flowing to the duodenum, and subsequently on PY (Santos et al., 1998). Supplying AA postruminally increases the AA supply to the dairy cow by a known amount, but still the milk protein response $(\mathbf{P Y} \boldsymbol{\Delta})$ to such supplementation is often variable. Similarly, postruminal infusion of casein has produced inconsistent results (Clark, 1975; Hanigan et al., 1998). 
Positive responses may not be observed because the supplemental AA may not have been limiting in the basal diet. Additionally, intestinal and hepatic AA metabolism have a major impact on the amount and profile of AA supplied to the mammary gland relative to intestinal disappearance and portal absorption (Seal and Reynolds, 1993). This is evident in the study of Blouin et al. (2002), in which it was demonstrated that the liver removes from 4 (Lys) to $80 \%$ (Ser) of the AA absorbed into the portal vein, so clearly the liver is changing the profile of AA available to the mammary gland relative to the amount absorbed from the gut.

The challenge therefore remains to accurately predict PY $\Delta$ to protein or AA supplementation. The model from the National Research Council (NRC, 2001) predicts PY using fixed efficiencies of conversion of metabolizable protein (MP) supply for maintenance (67\%), gestation (33\%), and milk production (67\%). The Cornell Net Carbohydrate and Protein System (CNCPS, 2000) also relates milk AA output to AA duodenal flow "devoted" to milk production using fixed efficiencies of conversion of essential AA (EAA) that vary among individual AA from 62 to 100\% (excluding Arg). However, the recovery of postruminally infused casein into milk protein averaged only $21 \%$ across 7 studies (Hanigan et al., 1998), which contrasts markedly with the efficiencies of conversion used by NRC (2001) or CNCPS (2000). This strongly suggests that the efficiency of conversion of AA to milk protein declines as AA supply approaches estimated requirements.

The current state of knowledge in the area of ruminant AA metabolism apparently does not allow for accurate prediction of PY in response to AA supply. Prediction schemes however do exist that attempt to relate AA supply to demand (O'Connor et al., 1993), and the NRC (2001) provides recommendations for Lys and Met supply relative to total MP based on Rulquin et al. (1993) and Schwab et al. (1992b). Rulquin et al. (2001) has also proposed requirements for other EAA based on a limited number of infusion studies.

Consequently, we integrated data from studies in which AA were infused postruminally in dairy cows with the objective of defining equations to predict PY and PY $\Delta$ as functions of AA supply. Our second objective was to use this data set to test our hypothesis that the efficiency of conversion of digestible AA into milk protein is not a constant as is assumed in current prediction schemes (CNCPS, 2000; NRC, 2001). Specifically, our aim was to determine the influence of AA supply on the variation of the efficiency of conversion of AA into milk and to estimate requirements for EAA. Because of the limitations of the data set, the equations and efficiency values reported herein are not intended to be used on a practical feed formulation level, but rather to expand our perspective of how AA recommendations could be generated.

\section{MATERIALS AND METHODS}

\section{Source of Data}

Data analyzed in this study originated from 40 publications encompassing 59 trials and 217 treatments (Appendix A). Each published treatment mean corresponds to an observation in the database. Because several publications in the database reported the results of more than one experiment, the observations were classified according to experiment within publication to account for unexplained variation between experiments. Published studies involving abomasal, duodenal, or intravenous infusions of casein or free AA were selected. With these studies the supply from the infusions was known exactly, thus reducing the dependence on the NRC (2001) prediction for AA supply (see explanation later in this section). Studies in which protein intake was manipulated by dietary means were not used because estimates of digestible AA supply would then rely entirely on the NRC (2001) predictions. Similarly, trials in which rumen-protected AA were fed were excluded due to the uncertainty associated with predicting the extent of rumen-protection of the AA. Within the infusion studies, only studies with information on feed intake and diet composition sufficient to estimate duodenal AA supply were used.

Thirty-three of the trials involved abomasal infusions, 8 involved intravenous infusions, 17 involved duodenal infusions, and 1 involved intravenous and abomasal infusions. In 53 of the trials, infusions were given continuously ( $>20 \mathrm{~h} / \mathrm{d})$. In 4 of the trials, infusions were given over a period of less than $10 \mathrm{~h} / \mathrm{d}$, and in 2 trials, both continuous and noncontinuous infusions were used. Infusions were administered on average for $11 \mathrm{~d}$ (SD 4.8), with a range of 4 to $28 \mathrm{~d}$. Two of the trials involved hyperinsulinemic-euglycemic clamps, and results obtained during administration of the clamp (4 observations) were excluded from the data set.

Of the 59 trials, Holstein (Friesian) cows were used in 52, Ayrshires were used in 5, and both Holsteins and Ayrshires were used in 1. In one trial, the breed of cow was not reported. The cows were multiparous in 58 of the 59 trials. Twenty-seven trials began in early lactation (<84 DIM), 29 began in midlactation (84 to 210 DIM), and 1 began in late lactation. Days in milk were not reported in 2 trials. Body weight was not given in 19 of the 59 trials. In these cases, BW was estimated using reported information from other papers by the same authors included in the database. Feed intake, BW, and milk production data are shown in Table 1. Of the 213 treatments analyzed, 57 were control treat- 
Table 1. Dry matter intake, BW, and milk production of cows from all studies in the database.

\begin{tabular}{|c|c|c|c|}
\hline & Mean & SD & Range \\
\hline DMI, kg & 17.7 & 3.3 & $9.1-27.6$ \\
\hline DIM, d & 98 & 53.5 & $7-220$ \\
\hline $\mathrm{BW}, \mathrm{kg}$ & 566 & 47.8 & $469-675$ \\
\hline Milk yield, $\mathrm{kg} / \mathrm{d}$ & 25.6 & 6.2 & $10.7-40.0$ \\
\hline Milk protein content, $\%^{1}$ & 2.9 & 0.2 & $2.5-3.5$ \\
\hline Milk protein yield, $\mathrm{g} / \mathrm{d}^{1}$ & 738 & 166 & $318-1105$ \\
\hline Milk protein yield response, $\mathrm{g}^{2}$ & 50.8 & 46.2 & $-66.6-184.1$ \\
\hline Milk protein yield response, $\%^{2}$ & 8.37 & 8.5 & $-7.1-39.8$ \\
\hline Milk fat content, $\%$ & 3.9 & 0.6 & $2.9-6.0$ \\
\hline Milk fat yield, g/d & 974 & 182 & 530-1602 \\
\hline
\end{tabular}

${ }^{1}$ Milk true protein; calculated as $\mathrm{CP} \times 0.93(\mathrm{NRC}, 2001)$.

${ }^{2}$ Difference in protein yield between treatment and control animals.

ments, 41 were casein (sodium or potassium caseinate) infusions, 9 were casein hydrolysate infusions, and 106 were free AA infusions. The number of AA infused ranged from 1 to 20 (Appendix A).

Nutrient intakes, net energy of lactation of the diet, MP supply, and predictions of digestible duodenal AA flows were estimated for each treatment using NRC (2001) based on the reported cow and diet information. If the nutrient composition of individual ingredients was published those values were used, otherwise, default model values (NRC, 2001) were used. If total diet composition was published, but not individual ingredient composition, composition of the forages was estimated so that diet composition values agreed with published values. Intestinal digestibility of the infusates was considered to be $100 \%$.

\section{Data Analysis}

Prediction of milk true protein yield. Principal component analysis was performed to determine which of the variables explained the majority of the variation in the data and to explore association among the variables (Jobson, 1992; SAS, 1999). The variables analyzed included production traits (PY, PY $\Delta$, DIM); and dietary traits [AA (digestible and infused), MP supply derived from diet, MP supplied from infusion, and total supply of net energy of lactation (NELT = diet + infusion]. Prediction equations for true milk PY (estimated as CP yield $\times 0.93(\mathrm{NRC}, 2001)$ when not published) using dietary components as predictors were obtained by regressing PY against NELT (Mcal/d), total CP supply $(\mathbf{C P T}=\mathrm{CP}$ diet $+\mathrm{CP}$ infusion, $\mathrm{g} / \mathrm{d})$, total MP supply (MPT = MP diet + MP infusion, g/d), and MPT and NELT together. Experiment within publication was included in the model as a random effect to account for variation between studies not described by other factors considered in the model. Regression analyses were performed with the MIXED procedure of SAS (1999). Intercept, linear, and quadratic terms were tested as fixed effects. A random shift on intercept and slope was modeled using experiment within publication as a subject, and a simple variance-covariance matrix for the random parameters. The PY $\Delta$ was calculated as the difference in PY between the infusion treatments and the control treatments within each experiment.

Modeling of PY as a function of AA supply. Milk true PY was modeled as a function of total supply of AA (AAT: dietary digestible plus infused AA). The NRC (2001) does not predict Trp or nonessential AA (NEAA) duodenal flows, so these terms were not included in any of the models tested. The AA in milk were estimated using the AA concentrations in milk reported by Jensen (1995). Linear and nonlinear functions were examined. The nonlinear models were fitted using a weighting of each observation based on the reported SEM of the milk protein yield in each experiment. A weighting variable was calculated for each observation by squaring the SEM and then dividing by the average of the squared SEM across all experiments (St-Pierre, 2001).

The linear function, a segmented-linear (also referred to as "broken-stick" or "bent-line") model, was fitted to the data using the model:

$$
\begin{gathered}
\hat{y}=a+b x\left(\text { for } x \leq x_{\mathrm{b}}\right) \text { and } \\
\hat{y}=a+b x_{\mathrm{b}}\left(\text { for } x \geq x_{\mathrm{b}}\right)
\end{gathered}
$$

such that $\hat{y}$ is the predicted yield of true protein or AA in milk (g/d), $x$ is AAT ( $\mathrm{g} / \mathrm{d}$; for example, total supply of His is referred to as HisT), $a$ is the intercept, $b$ is the slope, and $x_{b}$ is the value of $x$ beyond which the marginal efficiency $\left(\Delta_{y} / \Delta x\right)$ is equal to zero. This point, $x_{b}$, will be referred to as the breakpoint of the segmented-linear model. Estimates of $a, b$, and $x_{b}$ were obtained using the NLMIXED procedure of SAS (SAS, 1999).

As the majority of the data lay below the breakpoint, a linear model was tested with those data relating PY to all AAT and NELT. Variables with the largest $P$ - 
Table 2. Root mean square error (RMSE) and Akaike's information criteria (AIC) for three nonlinear models tested to model AA in milk as a function of AA supply. ${ }^{1}$

\begin{tabular}{|c|c|c|c|c|c|c|}
\hline \multirow[b]{2}{*}{$\mathrm{AA}$} & \multicolumn{2}{|c|}{ Michaelis-Menten } & \multicolumn{2}{|c|}{ Exponential } & \multicolumn{2}{|c|}{ Logistic } \\
\hline & RMSE & AIC & RMSE & AIC & RMSE & AIC \\
\hline Arg & 3.61 & 1135 & 3.58 & 1151 & 3.51 & 1129 \\
\hline His & 2.63 & 1008 & 2.61 & 1015 & 2.55 & 1002 \\
\hline Ile & 6.48 & 1388 & 6.43 & 1399 & 6.32 & 1382 \\
\hline Leu & 10.24 & 1581 & 10.07 & 1596 & 9.77 & 1565 \\
\hline Lys & 8.91 & 1507 & 8.87 & 1526 & 8.79 & 1506 \\
\hline Met & 2.79 & 1020 & 2.79 & 1037 & 2.79 & 1026 \\
\hline Phe & 5.28 & 1302 & 5.25 & 1320 & 5.19 & 1299 \\
\hline Thr & 4.47 & 1235 & 4.45 & 1255 & 4.30 & 1225 \\
\hline Val & 7.60 & 1455 & 7.55 & 1473 & 7.44 & 1451 \\
\hline
\end{tabular}

${ }^{1}$ Smaller RMSE and AIC indicate a better fit.

values were sequentially removed until the model contained only significant variables $(P<0.10)$. Residuals (observed-predicted) were then regressed against variables not used in the model to determine if additional terms would contribute to the power of the model. These additional terms included ADF intake, NDF intake, nonfiber carbohydrate intake, DIM, parity, BW, feeding frequency, and site and length of infusion. Only DIM was found to be significant and subsequently included in the model.

Final regression equations were obtained using Proc MIXED as descibed above. Michaelis-Menten, exponential, and logistic nonlinear functions were tested to predict PY as a function of AAT using the NLMIXED procedure in SAS (SAS, 1999). From the 3 models, the logistic model best fitted the observed data, based on the RMSE and Akaike's information criteria (AIC; SAS, 1999; Table 2). The logistic model selected had the form

$$
\hat{y}=\frac{A}{1+B e^{-\frac{x}{k}}}
$$

where $\hat{y}$ and $x$ are the same as in equation [1]; and $A$, $B$, and $k$ are the parameters of the function defining the ceiling of the response, the amplitude and the steepness of the curve, respectively.

For the final models presented, residuals were tested for heteroscedasticity using White's and Breusch-Pagan tests in the procedure MODEL of SAS (SAS, 1999).

Calculation of efficiency of conversion of $A A$. The total cumulative efficiency of conversion of individual AAT to milk protein was calculated as the ratio between the milk AA yield predicted from the fitted models $(\hat{y}$ : equations [1-3]) and the corresponding amount of total supply of an AA ( $x=\mathrm{AAT})$. Marginal total efficiency of conversion $(\Delta \hat{y} / \Delta x)$ was calculated from the ratio between increment of predicted PY and increment between corresponding supply (x). For the linear model, it is equal to the slope $b$ from equation [1], and for the logistic model, it is calculated from its first derivative [4]:

$$
\frac{d y}{d x}=\frac{A B e^{-\frac{x}{k}}}{k\left(1+B e^{-\frac{x}{k}}\right)^{2}}
$$

\section{Calculation of the optimal total supply of AA.} For the segmented-linear model, the parameter $x_{b}$ is assumed to represent the value of the optimal total supply of AA, because supply beyond this point would not increase the output of $y$. In the logistic model, the maximal $\hat{y}$ is attained at an infinite supply of $x$. Thus, an alternative approach to estimate the optimal total supply of AA is outlined as follows. In the logistic function, the marginal efficiency (equation [4]; Figure 1) first increases exponentially, reaches a maximum, and decreases exponentially, giving the logistic curve its characteristic sigmoid form with point of symmetry equal to the maximum marginal efficiency. In each of these symmetrical halves it is possible to define a "critical point" in which the function either starts a faster increase or decrease (i.e., the points defining the curvature of the "S"). These critical points can be defined as the minimum and maximum values of the second derivative of the logistic function (Figure 1). Algebraically, it is possible to define these two critical points (lower: $x_{L}$ and upper: $x_{U}$ ) as

$$
\begin{gathered}
x_{\mathrm{L}}=k \log (2 B-\sqrt{3 B}) \\
\text { and } x_{\mathrm{U}}=k \log (\sqrt{3 B}+2 B)
\end{gathered}
$$

such that $x_{L}$ and $x_{U}$ are the values of $x$ (AAT) where the marginal efficiency increases or decreases rapidly, respectively; and $B$ and $k$ are the parameters for the logistic equation fitted to individual AA (Grossman, 


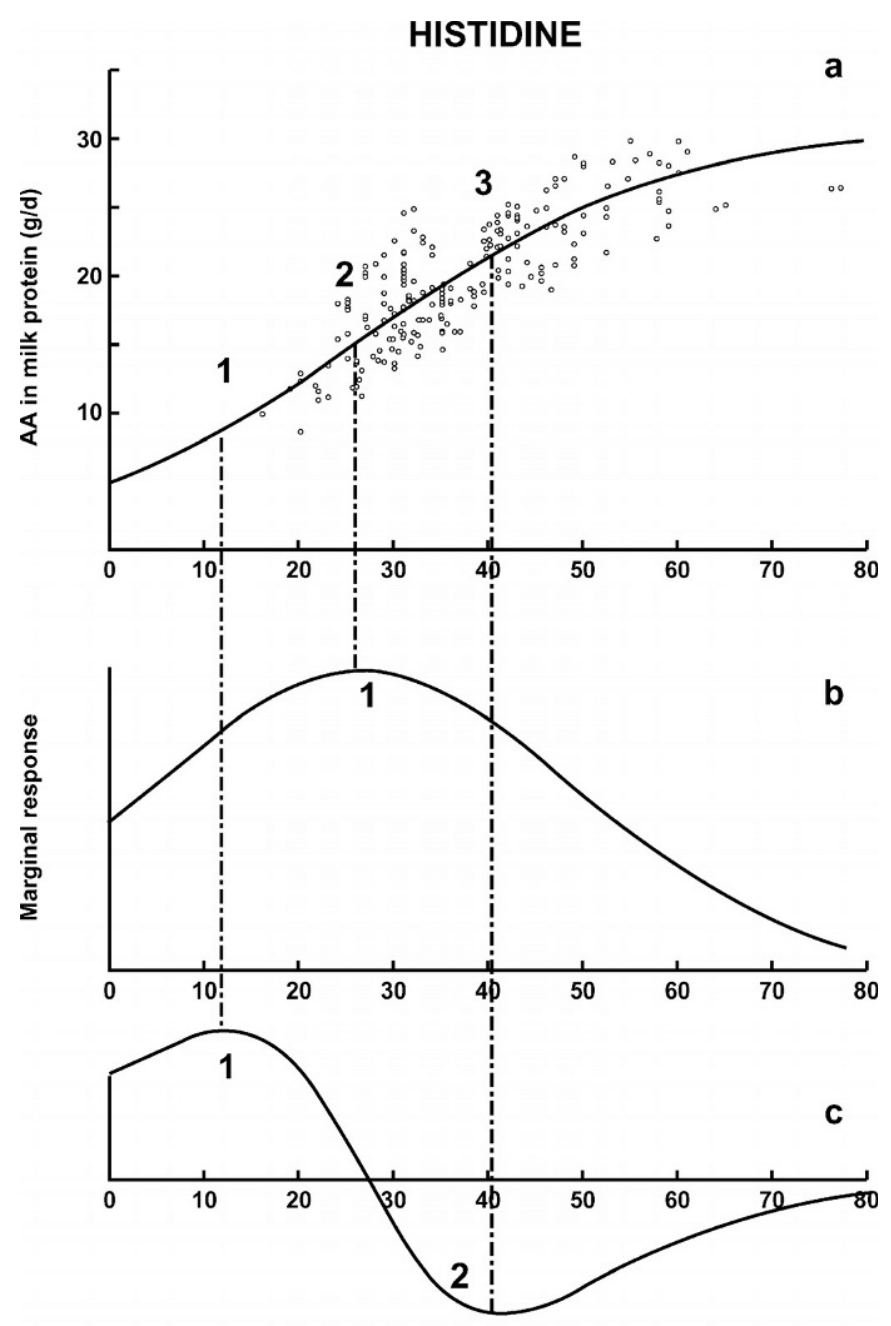

Total estimated supply $\left(\mathrm{AA}_{\boldsymbol{i}} \mathrm{T} ; \mathrm{g} / \mathrm{d}\right)$

Figure 1. Visual representation of the fitted logistic function superimposed on the observed values (a); together with its first (b) and second (c) derivatives. The curve (b) represents the marginal efficiency. The maximum marginal efficiency (a2, b1) is calculated from the first derivative, and the lower (a1, c1) and upper (a3, c2) critical points are calculated from the second derivative. The upper critical point is assumed to represent the requirement for duodenal AA supply (see text for explanation).

1986). The upper critical point $\left(x_{U}\right)$ was assumed to represent the optimum for AAT, as supply in excess of this value results in marginal efficiencies rapidly approaching zero. The individual AAT that corresponded to the optimum $\left(x_{b}\right.$ for the segmented-linear and $x_{U}$ for the logistic models) were summed to give optimum supply of total EAA. The proportion of each EAA in total EAA was then calculated, with the proportion being indicative of the required relative contribution of each AA to an "ideal" pattern of metabolizable EAA. Approximate standard errors for the require- ments (absolute amounts and amounts relative to EAA) were calculated using the ESTIMATE option of the NLMIXED procedure in SAS (SAS, 1999). Essential AA requirements were also determined on an MP basis assuming that EAA represent $48 \%$ of MP (average for the database).

Calculation of the efficiencies of conversion of $\boldsymbol{A A}$ for lactation. In addition to total efficiency of conversion, the efficiency for lactation was calculated using the AA supply only available for milk, with the maintenance requirement (see below for estimation of requirement) of each AA being subtracted from AAT. Therefore, the linear and the logistic functions were fitted again, this time with the $x$ being only the AA available for milk. For the segmented-linear model, the 'no intercept' option was used with the assumption that body stores are not contributing to milk PY, therefore when AA available for milk are zero, AA yield in milk is assumed to be zero. The maintenance requirement of each AA was calculated from the estimated NRC (2001) maintenance requirement expressed as $\mathrm{MP}$, with the appropriate composition of AA for each component (Table 3). The four components that comprise the maintenance MP requirement are scurf protein, urinary protein, metabolic fecal protein, and endogenous protein (NRC, 2001). To calculate the scurf requirement, the AA composition of keratin (Block and Bolling, 1951) was used. For the urinary requirement, whole empty body composition was used (Williams, 1978; Rohr and Lebzien, 1991; Ainslie et al., 1993). Metabolic fecal protein consists of various compounds including mucous secretions, bile pigments, sloughed epithelial cells, bacterial debris, and keratinized cells (O'Connor et al., 1993; NRC, 2001). According to NRC (2001), the bacterial contribution to metabolic fecal protein was calculated as $0.5 \times$ (bacterial MP/0.8 - bacterial MP). The AA composition of endogenous protein from rumen fluid was used to estimate the AA requirement for this component (Ørskov et al., 1986). The remainder of the metabolic fecal protein requirement was calculated as metabolic fecal protein less the bacterial contribution, and was assumed to be of intestinal origin. The AA composition of porcine intestinal endogenous protein (Stein et al., 1999; de Lange et al., 1989a, 1989b) was used for this requirement. In these studies, the endogenous protein composition was determined in animals fed protein-free diets.

\section{RESULTS}

\section{Principal Component Analysis}

Principal component analysis revealed the relative dependence of PY and PY $\Delta$ on digestible nutrients arriving at the duodenum either as a result of the diges- 
Table 3. Amino acid composition of tissue and endogenous proteins ( $\mathrm{g} 100 \mathrm{~g}^{-1}$ total AA) used for the estimation of maintenance requirements.

\begin{tabular}{|c|c|c|c|c|c|c|}
\hline AA & $\begin{array}{l}\text { Whole } \\
\text { empty } \\
\text { body }\end{array}$ & $\begin{array}{l}\text { Abomasal } \\
\text { isolate }^{2}\end{array}$ & $\begin{array}{l}\text { Ruminal } \\
\text { isolate }^{3}\end{array}$ & $\begin{array}{l}\text { Intestinal } \\
\text { isolate }^{4}\end{array}$ & $\begin{array}{l}\text { Intestinal } \\
\text { isolate }^{5}\end{array}$ & Keratin $^{6}$ \\
\hline Arg & 7.3 & 4.9 & 6.2 & 3.9 & 4.0 & 4.4 \\
\hline His & 2.7 & 3.6 & 3.4 & 1.6 & 2.0 & 1.2 \\
\hline Ile & 3.1 & 4.6 & 4.7 & 3.2 & 4.0 & 5.8 \\
\hline Leu & 7.4 & 4.8 & 9.0 & 5.3 & 6.6 & 11.6 \\
\hline Lys & 7.0 & 7.3 & 7.7 & 3.9 & 5.4 & 3.7 \\
\hline Met & 2.2 & 1.5 & 1.6 & 1.2 & 2.0 & 1.2 \\
\hline Phe & 3.9 & 4.6 & 5.0 & 4.0 & 7.1 & 4.3 \\
\hline Thr & 4.3 & 6.5 & 6.0 & 5.4 & 7.9 & 8.4 \\
\hline Trp & 0.8 & 1.9 & 1.8 & 1.7 & 1.7 & 1.6 \\
\hline Val & 4.4 & 6.1 & 6.2 & 4.2 & 6.0 & 7.0 \\
\hline Ala & & 5.6 & 6.0 & 5.0 & 5.6 & \\
\hline Asp & & 9.1 & 3.0 & 7.9 & 9.8 & \\
\hline Cys & & 3.2 & 2.6 & 2.3 & 2.3 & \\
\hline Glu & & 12.4 & 15.0 & 9.5 & 11.4 & \\
\hline Gly & & 6.4 & 5.6 & 11.1 & 8.1 & \\
\hline Pro & & 6.2 & 6.0 & 21.9 & 5.6 & \\
\hline Ser & & 6.5 & 5.6 & 4.9 & 6.3 & \\
\hline Tyr & & 4.9 & 4.7 & 2.9 & 3.9 & \\
\hline
\end{tabular}

${ }^{1}$ Average of values from Ainslie et al. (1993), Rohr and Lebzien (1991), and Williams (1978).

${ }^{2}$ Orskov et al. (1986), except Trp (Stein et al., 1999).

${ }^{3}$ Average of values from Stein et al. (1999; lactating sows and growing pigs) and de Lange et al. (1989a, $1989 \mathrm{~b}$; control treatments).

${ }^{4}$ de Lange et al. (1989b; AA treatment).

${ }^{5}$ Block and Bolling (1951).

tion of the diet or supplied by the infusions. The first principal component comprised the basal digestible duodenal AA flow together with $\mathrm{NE}_{\mathrm{L}}$ intake. The second principal component comprised the supplemental AA from the infusates. The first and second principal components explained 65 and $20 \%$ of the total variance, respectively. Addition of a third principal component containing DIM and BW increased this value an additional 5\%. Protein yield was positively related to both AA infused and digestible AA in duodenal flow and inversely related to DIM. The PY $\Delta$ was negatively correlated with digestible duodenal AA flow (first principal component), and poorly correlated with supplemental AA (second principal component).

\section{Milk Protein Yield}

After accounting for a significant $(P<0.01)$ random effect of experiment on slope, PY and NELT were linearly related (equation 4.1 , Table 4 ). In contrast, the PY relationships with CPT and MPT were quadratic (equations 4.2 and 4.3 , Table 4 ), with a significant ( $P$ $<0.01$ ) random effect of experiment on intercepts. The prediction of PY was improved when MPT replaced CPT in the model (cf. equations 4.2 and 4.3). Prediction of PY was only marginally improved by including both the NELT and MPT terms (equation 4.4). From the observations of the principal component analysis, it was concluded that a regression model that included AAT and NELT would account for the majority of the variation in PY. Therefore, for data below the breakpoint determined by the segmented-linear model, PY was regressed against AAT and NELT. Removal of the nonsignificant terms and addition of the DIM term resulted in an equation containing HisT, LysT, MetT, NELT, and DIM (equation 4.5, Table 4). To determine whether any one of these $3 \mathrm{AA}$ had a dominant role in determining PY, PY was regressed against NELT, DIM, and each of these three AA individually. The residual variance after fitting the models for these AA was similar (data not shown), indicating that PY is not dependent on only one AA but that the AA are highly interrelated. Regression and principal component analyses did not identify any significant relationships between PY $\Delta$ and AA infused, dietary digestible AA, AAT, or NELT. As a result, further attempts to generate prediction equations for PY $\Delta$ were not pursued.

Attempts to model the random effects of experiment for both the segmented-linear and logistic models resulted in unstable solutions due to the limited number and spread of data within each experiment. Therefore, all results presented are inferred from the fixed effectsonly models. Both the segmented-linear and logistic models were similar in their ability to describe the relationship between PY and AAT, based on their root mean square error (Figure 2). Due to the different way they 
Table 4. Prediction equations for milk true protein yield (PY), g/d.

\begin{tabular}{|c|c|c|c|c|c|c|c|c|}
\hline Equation & $\begin{array}{l}\text { Dependent } \\
\text { variable }\end{array}$ & $\mathrm{n}$ & Intercept & $\mathrm{SE}$ & $\begin{array}{l}\text { Independent } \\
\text { variable }^{1}\end{array}$ & Coefficient $^{2}$ & $\mathrm{SE}$ & $\mathrm{AIC}^{3}$ \\
\hline 4.1 & PY & 213 & $-73.8^{4}$ & 44.8 & NELT & 29.04 & 1.57 & 2348 \\
\hline 4.2 & PY & 213 & -190.4 & 83.9 & $\begin{array}{l}\mathrm{CPT} \\
\mathrm{CPT} \times \mathrm{CPT}\end{array}$ & $\begin{array}{l}0.46 \\
-0.000041\end{array}$ & $\begin{array}{l}0.06 \\
0.00001\end{array}$ & 2346 \\
\hline 4.3 & PY & 213 & $39.3^{4}$ & 56.4 & $\begin{array}{l}\text { MPT } \\
\mathrm{MPT} \times \mathrm{MPT}\end{array}$ & $\begin{array}{l}0.51 \\
-0.000062\end{array}$ & $\begin{array}{l}0.06 \\
0.000016\end{array}$ & 2315 \\
\hline 4.4 & PY & 213 & -187.4 & 66.2 & $\begin{array}{l}\text { NELT } \\
\text { MPT } \\
\text { MPT } \times \text { MPT }\end{array}$ & $\begin{array}{l}14.16 \\
0.42 \\
-0.000065\end{array}$ & $\begin{array}{l}2.58 \\
0.06 \\
0.000015\end{array}$ & 2291 \\
\hline 4.5 & PY & 175 & $-35.7^{4}$ & 46.9 & $\begin{array}{l}\text { HisT } \\
\text { LysT } \\
\text { MetT } \\
\text { NELT } \\
\text { DIM }\end{array}$ & $\begin{array}{r}4.27 \\
0.65 \\
1.68 \\
20.04 \\
-0.70\end{array}$ & $\begin{array}{l}1.02 \\
0.27 \\
0.75 \\
2.22 \\
0.09\end{array}$ & 1850 \\
\hline
\end{tabular}

${ }^{1} \mathrm{NELT}=$ net energy supply from diet and infusion in Mcal/d; CPT = total dietary $\mathrm{CP}$ supply from diet and infusion in $\mathrm{g} / \mathrm{d} ; \mathrm{MPT}=$ total metabolizable protein from diet and infusion in $\mathrm{g} / \mathrm{d} ; \mathrm{AAT}=$ digestible duodenal AA flow + infusion in g/d.

${ }^{2}$ Coefficient for fixed effects after adjustment for the random effect of experiment.

${ }^{3} \mathrm{AIC}=$ Akaike's information criteria after adjustment for the random and fixed effects of experiment: smaller value indicates a better fit.

${ }^{4}$ Intercept not significantly different from zero.

were defined, the optimum absolute amounts of AA estimated with the logistic model were on average $88 \%$ of the estimates from the broken stick model (Table 6). However, when the results are expressed as a percentage of EAA total supply, or as a percentage of MP, the values from the 2 models were similar (Table 6).

\section{Efficiency of Amino Acid Use}

Efficiency of conversion of dietary CP for milk protein secretion in the control treatments, calculated as PY/ CPT, was 0.27. When expressed on an MP basis (PY/ $\mathrm{MPT}$ ), efficiency increased to 0.42 . The efficiency of con-

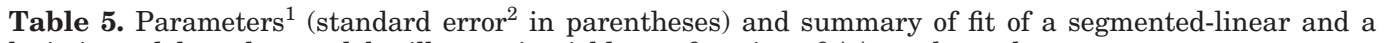
logistic model used to model milk protein yield as a function of AA total supply.

\begin{tabular}{|c|c|c|c|c|c|}
\hline \multirow[b]{2}{*}{$\mathrm{AA}$} & \multicolumn{3}{|c|}{ Parameters of segmented-linear model } & \multirow[b]{2}{*}{ RMSE } & \multirow[b]{2}{*}{ Adj. $R^{2}$} \\
\hline & $a$ & $b$ & $x_{b}$ & & \\
\hline Arg & $80(39)$ & $8.7(0.6)$ & 107 & 98.5 & 0.65 \\
\hline His & $135(31)$ & $16.4(0.9)$ & 53 & 89.9 & 0.71 \\
\hline Ile & $79(41)$ & $7.9(0.5)$ & 118 & 102.7 & 0.62 \\
\hline Leu & $156(34)$ & $3.9(0.3)$ & 211 & 95.0 & 0.68 \\
\hline Lys & $96(37)$ & $5.4(0.3)$ & 162 & 102.0 & 0.63 \\
\hline Met & $194(26)$ & $15.3(0.8)$ & 57 & 94.5 & 0.69 \\
\hline Phe & $116(38)$ & $7.3(0.5)$ & 117 & 102.8 & 0.63 \\
\hline Thr & $-30(39)$ & $9.3(0.5)$ & 113 & 91.9 & 0.70 \\
\hline \multirow[t]{2}{*}{ Val } & $110(40)$ & $6.5(0.4)$ & 136 & 110.8 & 0.57 \\
\hline & $A$ & $k$ & $B$ & RMSE & Adj. $R^{2}$ \\
\hline Arg & $1100(53)$ & $26.8(3.7)$ & $7.9(1.9)$ & 99.1 & 0.65 \\
\hline His & $1148(70)$ & $16.2(2.2)$ & $5.2(0.7)$ & 91.3 & 0.70 \\
\hline Ile & $1127(72)$ & $32.4(5.2)$ & $6.8(1.5)$ & 104.7 & 0.61 \\
\hline Leu & $1072(46)$ & $57.7(7.5)$ & $5.6(1.0)$ & 97.8 & 0.66 \\
\hline Lys & $1094(60)$ & $44.1(6.03)$ & 6.7 (1.4) & 101.4 & 0.64 \\
\hline Met & $1194(91)$ & 18.0 & $4.3(0.5)$ & 94.5 & 0.69 \\
\hline Phe & $1132(76)$ & 35.1 & $5.9(1.2)$ & 104.7 & 0.61 \\
\hline Thr & $1117(56)$ & $26.3(3.4)$ & 11.3 & 92.7 & 0.70 \\
\hline Val & $1171(104)$ & $41.7(7.9)$ & $5.9(1.2)$ & 112.7 & 0.55 \\
\hline
\end{tabular}

${ }^{1}$ See text for explanation about each parameter.

${ }^{2}$ Standard errors cannot be reliably estimated for the breakpoint. 

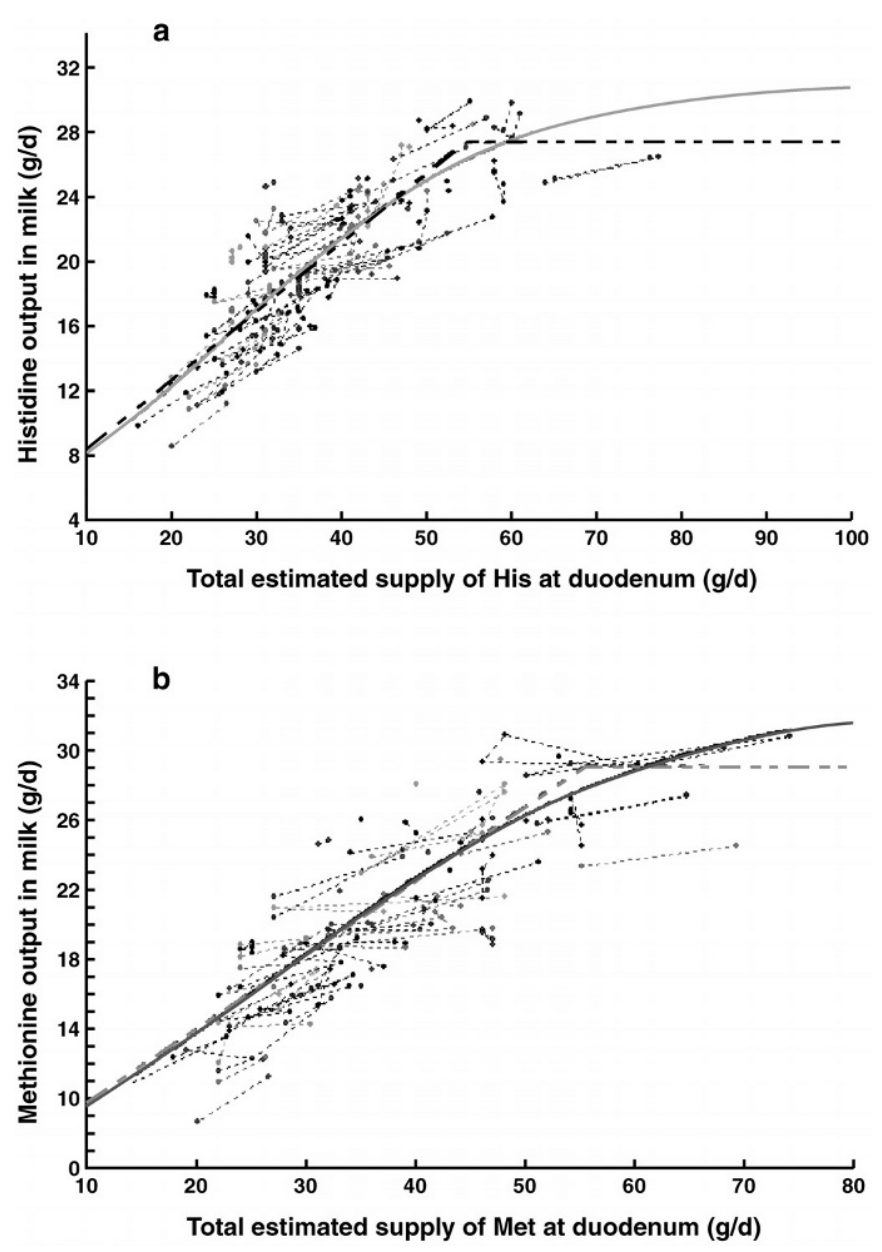

Figure 2. Graphical representation of the data sets for His and Met. Data points from the same experiment are connected by dotted lines. The logistic (solid line) and segmented linear (dashed line) fitted models are superimposed. version for lactation of either MPT or AAT considers only the MPT or AAT that is available for milk production, i.e., the requirement for maintenance has been subtracted from the total amount available. The efficiency of MP conversion for lactation calculated using the segmented-linear model averaged 0.72 , for values of total supply below the breakpoint $x_{b}$. For the logistic model, milk protein and AA in milk exhibited diminishing return behavior. The efficiency of conversion was higher at low levels of supply and decreased as AA supply increased. At 50\% of the calculated optimal supply, efficiency of MP conversion for lactation was on average 0.91 , and decreased to an average of 0.64 at the optimum supply.

For both the segmented-linear and the logistic models, variation in the efficiency of conversion among AA was shown (Table 7). With both models, and across all trials and milk PY, His was the most efficiently used $\mathrm{AA}$, and Arg the least efficiently used. For comparison, the efficiency values used in version 4 of the CNCPS (2000) prediction model are also presented in Table 7.

\section{DISCUSSION}

\section{Protein Yield}

The relationship between PY and MPT was better than the relationship between PY and CPT. This is to be expected since MP is protein available to the animal at the intestinal level, while $\mathrm{CP}$ is merely a reflection of dietary protein and nonprotein nitrogen that is subject to net losses during ruminal fermentation. Total net energy of lactation was a better predictor of PY than was MPT: in ruminants, energy intake has effects on both protein and energy supplies. Energy intake directly affects the amount of energy available to the animal, which, translated into glucose and acetate supply to the mammary gland, is needed to support high levels of milk production. In addition to this, energy

Table 6. Optimal absolute and relative amounts of digestible AA supply estimated from segmented-linear and logistic curve models.

\begin{tabular}{|c|c|c|c|c|c|c|}
\hline \multirow[b]{2}{*}{ AA } & \multicolumn{3}{|c|}{ Segmented-linear model } & \multicolumn{3}{|c|}{ Logistic model } \\
\hline & $\mathrm{g} / \mathrm{d}$ & $\% \mathrm{EAA}^{1}$ & $\% \mathrm{MP}^{2}$ & $\mathrm{~g} / \mathrm{d}$ & $\% \mathrm{EAA}$ & $\% \mathrm{MP}$ \\
\hline Arg & 107 & 10.0 & 4.8 & 91 & 9.6 & 4.6 \\
\hline His & 53 & 4.9 & 2.4 & 48 & 5.1 & 2.4 \\
\hline Ile & 118 & 11.0 & 5.3 & 105 & 11.1 & 5.3 \\
\hline Leu & 211 & 19.7 & 9.4 & 175 & 18.5 & 8.9 \\
\hline Lys & 162 & 15.1 & 7.2 & 142 & 15.0 & 7.2 \\
\hline Met & 56 & 5.2 & 2.5 & 50 & 5.3 & 2.5 \\
\hline Phe & 117 & 10.9 & 5.2 & 108 & 11.4 & 5.5 \\
\hline Thr & 113 & 10.5 & 5.1 & 98 & 10.4 & 5.0 \\
\hline Val & 136 & 12.7 & 6.1 & 129 & 13.6 & 6.5 \\
\hline
\end{tabular}

${ }^{1}$ EAA: essential AA, excluding Trp.

${ }^{2} \mathrm{MP}$ : metabolizable protein, assuming that EAA represent $48 \%$ of MP. 
Table 7. Efficiencies of utilization ${ }^{1}$ of AA for lactation after discounting the maintenance ${ }^{2,3}$ requirements from total AA supply.

\begin{tabular}{|c|c|c|c|c|c|c|}
\hline \multirow[b]{4}{*}{ AA } & \multicolumn{6}{|c|}{ Efficiency of conversion of AA for milk } \\
\hline & \multirow{3}{*}{$\frac{\begin{array}{c}\text { Linear } \\
\text { model }\end{array}}{\text { (fixed) }}$} & \multicolumn{4}{|c|}{ Logistic model } & \multirow{3}{*}{$\begin{array}{l}\text { CNCPS } \\
(2000) \\
\text { (fixed) }\end{array}$} \\
\hline & & \multicolumn{4}{|c|}{$\%$ of optimum supply } & \\
\hline & & $50 \%$ & $75 \%$ & $100 \%$ & $125 \%$ & \\
\hline Arg & 0.59 & 0.71 & 0.57 & 0.49 & 0.44 & 0.35 \\
\hline His & 0.95 & 1.09 & 0.88 & 0.76 & 0.68 & 0.96 \\
\hline Ile & 0.74 & 0.86 & 0.72 & 0.65 & 0.58 & 0.66 \\
\hline Leu & 0.70 & 0.83 & 0.70 & 0.61 & 0.55 & 0.72 \\
\hline Lys & 0.77 & 0.90 & 0.76 & 0.68 & 0.60 & 0.82 \\
\hline Met & 0.80 & 0.89 & 0.75 & 0.66 & 0.59 & 1.00 \\
\hline Phe & 0.64 & 0.75 & 0.61 & 0.53 & 0.48 & 0.98 \\
\hline Thr & 0.69 & 0.82 & 0.67 & 0.60 & 0.55 & 0.78 \\
\hline Val & 0.76 & 0.86 & 0.71 & 0.62 & 0.56 & 0.62 \\
\hline
\end{tabular}

${ }^{1}$ Calculated from AA in milk as a function of AA available for milk.

${ }^{2}$ Maintenance requirements included scurf protein, urinary protein, metabolic fecal protein, and endogenous protein (NRC, 2001).

${ }^{3}$ The intestinal endogenous AA composition used to calculate maintenance requirements is the average of Stein et al. (1999; lactating sows and growing pigs) and de Lange et al. (1989a, 1989b; control treatments)

availability (from nonfat sources) in the rumen is a regulating factor of microbial protein yield, which usually accounts for more than $50 \%$ of the duodenal protein flux (Lynch et al., 1991; Schwab et al., 1992a). In the present study, estimations of bacterial MP accounted for 55\% of estimated total MP supply. Indeed, energy content of the diet has had a greater impact on AA portal absorption in growing steers than the $\mathrm{CP}$ content of the diet (Reynolds et al., 1992).

The principal component analysis revealed that total AA supply and NELT are the primary determinants of PY. As previously discussed, energy supply is a major factor regulating MP supply. Thus, it is to be expected that these two factors would be the most influential in determining PY. The regression equation that explained most of the variation in the PY data (equation 4.5, Table 4) also agrees well with the observations of the principal component analysis. The positive coefficients of HisT, LysT, and MetT indicate that as the supply of these AA increases, PY increases. Lys and Met are often considered to be first and second limiting for milk protein synthesis (Schwab et al., 1992a; Guinard and Rulquin, 1994). Vanhatalo et al. (1999) suggested that His was first limiting when grass silage diets were fed. Although this equation suggests that His, Lys, and Met may be limiting, it must be remembered that in the majority of these studies, other AA were infused, so the possibility also exists that several AA are co-limiting.

One of the main objectives of this work was to produce equations to predict the PY $\Delta$ to supplementary AA. However, we were not able to detect a significant association between the magnitude and direction of the PY $\Delta$ and the changes in AA supply from the diets or the infusion across the studies in our database.

\section{Requirements for Essential AA}

In terms of absolute amounts, the estimation of optimum AA supply using the logistic model yielded values that were, on average, $88 \%$ of those estimated with the segmented-linear model. This is most likely the result of the different assumptions used to define the optimum supply in the two models. For the segmented-linear model, optimum supply is assumed when the efficiency is equal to zero, whereas the value for the logistic model is estimated assuming that the efficiency approaches zero. However, when the optimum values are represented as the amount of AA relative to total EAA and MP, both the linear and logistic models yielded fairly similar recommendations (Table 6). The recommendations for digestible Lys and Met, expressed as the percentage of total EAA are 15.1 and 5.2\% and 15.0 and $5.3 \%$ for the segmented-linear and the logistic models, respectively. Both models agree with the current Lys recommendations (NRC 2001, 7.2\% of MP; Rulquin et al., $1993,7.3 \%$ of protein truly digested in the small intestine [PDI]) when expressed on an MP basis. Our estimates of the optimal supply of Met (2.5\% of MP) are slightly greater than the $2.4 \%$ recommended by NRC, but match the $2.5 \%$ of PDI suggested by Rulquin et al. (1993).

The recommended allowance of $2.4 \%$ of MP for His is similar to that for Met. This value is considerably lower than that reported by Rulquin and Pisulewski (2000b), who suggested that the requirement for metab- 
olizable His was between 3.4 and $5.6 \%$ of PDI. Considering the similarities between His and Met in terms of their hepatic uptake (Blouin et al., 2002), mammary gland uptake to output ratio (Guinard and Rulquin, 1995), and abundance in milk protein, a similar value for the recommendations of these AA seems biologically valid.

The recommendation for Leu (9.4 and $8.9 \%$ of MP for the linear and the logistic models, respectively) is consistent with Rulquin and Pisulewski (2000a), who recommended that Leu as a percentage of PDI be between 8.9 and $11.1 \%$. These values are both in agreement with CNCPS (2000). The allowances for the other 2 branched-chain AA are also consistent with CNCPS (2000) and Rulquin et al. (2001). The Phe allowance (5.2 and 5.5\% of MP for the linear and logistic models, respectively) is also in agreement with Rulquin and Pisulewski (2000c), who recommended a level between 4.6 and $5.8 \%$ of PDI.

\section{Efficiency of Amino Acid Use}

The use of the segmented-linear model is mathematically advantageous as it allows us to determine simply an estimate of $\mathrm{AA}$ requirements. Biologically, this model is somewhat simplistic as it suggests that below the breakpoint the efficiency of conversion of AA is constant, and beyond this breakpoint there is no increase in PY in response to increasing supplies of AA. Both Guinard et al. (1994) and Whitelaw et al. (1986) demonstrated diminishing partial efficiencies of protein use for milk protein synthesis. In the study of Guinard et al. (1994), the efficiency of converting PDI into milk protein decreased from 0.47 to 0.38 as PDI increased from 1403 to $2073 \mathrm{~g} / \mathrm{d}$ as a result of casein infusions (from 0 to $762 \mathrm{~g} / \mathrm{d}$ ). Whitelaw et al. (1986) reported that a $200 \mathrm{~g} / \mathrm{d}$ infusion of casein increased PY by $81 \mathrm{~g} / \mathrm{d}$, whereas a 600-g infusion only increased PY by $158 \mathrm{~g} /$ $d$. The use of a fixed efficiency factor in current models would at least partially explain why observed responses to supplemental protein are usually less than predicted (Bequette et al., 1998).

With current ration evaluation programs (CNCPS, 2000; NRC, 2001), increased flow of digestible AA at the duodenum is predicted to result in increased milk protein synthesis because of the assumptions that mammary gland AA supply is positively correlated with duodenal supply, that milk protein secretion is directly related to AA supply to the mammary gland, and that the efficiency of AA use is constant. The logistic model in the present study suggests that efficiency of AA use is not constant. The question then is, why would MP be used with diminishing efficiency for milk protein synthesis as its supply is increased? It may be partially attributable to changes in mammary blood flow and inefficiencies within the mammary gland. Guinard and Rulquin (1995) observed a quadratic decrease in mammary blood flow as the amount of infused Met increased from 0 to $32 \mathrm{~g} / \mathrm{d}$, with a concomitant decrease in extraction rate such that mammary gland Met uptake was unchanged. Bequette et al. (1996) reported an increased oxidation of Leu across the mammary gland as the supply of Leu increased. Diminished efficiency may also relate to metabolism in nonmammary tissues, which would reduce the AA supply to the mammary gland. Liver extraction of AA relative to portal absorption increases at higher AA supply, such that the increment in post-liver supply is much smaller than the increment in portal absorption (Guerino et al., 1991; Bruckental et al., 1997). It is still not clear if the liver is then acting to remove non-used excess AA or is having a cut on the first pass after absorption (Lobley, 2002). Therefore, as several studies have demonstrated that productive responses to AA supplementation in lactating dairy cows are not linear (Whitelaw et al., 1986; Rulquin et al., 2001), a mathematical model that allows for the changing efficiency of conversion of absorbed AA to milk protein will be a better tool to predict productive responses to dietary manipulation in dairy cows. In nonruminants, the logistic function has been used to describe the diminishing return responses to AA supplementation (Gahl et al., 1994, 1996). In our study, using the parameters from the logistic fit, this efficiency value was substantially different below and above the estimated optimum ( 0.91 vs. 0.56 at $50 \%$ vs. $125 \%$ of the optimum intake, respectively). These data, although applicable only to a restricted data set, clearly show that it is possible to mathematically estimate a variable coefficient for the conversion of MP to milk protein. The logistic model allows for the use of different marginal efficiencies of conversion depending on the level of AA supplied. Across AA, the marginal efficiency of conversion of digested AA into milk averaged $28 \%$ at the optimum supply and $19 \%$ for values $125 \%$ of the optimum. This marginal efficiency is in agreement with the $21 \%$ marginal efficiency reported by Hanigan et al. (1998) when casein was infused above the estimated MP requirements.

For the linear model, the efficiency of AA conversion for lactation (AA in milk/[AAT - AA for maintenance]) varied considerably among AA, ranging from a low of 0.59 for Arg to a high of 0.95 for His. A similar pattern was observed for the logistic equation. The efficiency values for the 3 branched-chain AA ranged from 0.70 to 0.76 , which are in close agreement with those used in the CNCPS (2000) model (0.62 to 0.72). Likewise, the efficiency value for His and Lys are also in agreement with those of CNCPS (2000). 
Although Met was the second most efficiently used $\mathrm{AA}$ in this study, its calculated efficiency of $80 \%$ is substantially below the CNCPS value of $100 \%$. The difference between the 2 values may be a reflection of the methodology used to calculate the efficiency values. The CNCPS value is based on the ratio of mammary gland AA uptake to milk AA output (Overton, personal communication). The uptake of Met by the mammary gland in a 1:1 ratio with its output in milk (Guinard and Rulquin, 1994 and 1995), and its minimal catabolism in the mammary gland contribute to its high efficiency value (Mepham, 1982). The high efficiency of conversion of His can be explained by its metabolism, which in terms of its extraction by the liver (Blouin et al., 2002) and its uptake by the mammary gland relative to its output in milk, parallels that of Met (Guinard and Rulquin, 1995).

The efficiency of conversion of Phe $(0.64$ for the linear model, 0.53 for the logistic model) for lactation was low relative to that predicted by CNCPS (0.98; CNCPS 2000). Several possible explanations exist to account for this difference. First, it is possible that Phe was not limiting in the basal diets in the studies used in our database, and so additional Phe supplied by the infusions was not incorporated into milk protein but simply catabolized. Second, the maintenance requirement for Phe as calculated in this study may be underestimated because of the assumptions that were made regarding metabolic fecal protein requirements. Because metabolic fecal protein requirements comprise such a large proportion $(\sim 64 \%)$ of MP maintenance requirements, alterations in intestinal endogenous protein AA composition will have a major impact on the efficiency of AA use for lactation. For example, a $20 \%$ increase in Phe efficiency of use was obtained simply by changing the composition of the intestinal endogenous loss from 4.0 (Table 3) to $7.1 \%$ (obtained under AA infusion; de Lange et al., 1989b). The fact that a calculated efficiency can be increased by up to $20 \%$ so easily raises an important question-how should maintenance requirements be calculated? If the approach taken in the current study is considered reasonable and worth refining, what are the AA profiles of the constituent maintenance components that should be used? Clearly, this is an area that warrants further research.

The efficiency of Arg use, calculated to be 0.59, is considerably higher than the 0.35 used by CNCPS. This discrepancy may be attributable to endogenous synthesis of Arg from citrulline. In human adult males, the conversion of citrulline to Arg accounted for 9\% of whole-body Arg flux (Castillo et al., 1993). The whole body irreversible loss rate of Arg is approximately 80\% of that of Leu (Lobley et al., 1996). In the dairy cow, this would translate to a whole body irreversible loss rate of Arg of $80 \mathrm{mmol} / \mathrm{h}$ (Lapierre et al., 2002). Assuming that $9 \%$ of this is derived from de novo synthesis, then daily Arg synthesis is approximately $30 \mathrm{~g} / \mathrm{d}$. Addition of this amount of Arg to the total supply (ArgT) reduces the efficiency of conversion to 0.35 .

\section{CONCLUSION}

Requirements for EAA relative to MP have been estimated using a limited number of publications. In spite of the limitations in our database, our estimations are in close agreement with currently accepted recommendations for Lys and Met, which suggests a certain reliability for our estimations for other AA. Also, demonstration has been made that the efficiency of conversion of metabolizable AA use for milk PY is not constant, but varies according to metabolizable AA supply and among individual AA. The inclusion of recommended allowances for the whole range of EAA, together with the use of variable efficiency factors, should improve our ability to predict PY in response to supplemental protein in lactating dairy cows.

\section{REFERENCES}

Ainslie, S. J., D. G. Fox, T. C. Perry, D. J. Ketchen, and M. C. Barry. 1993. Predicting amino acid adequacy of diets fed to Holstein steers. J. Anim. Sci. 71:1312-1319.

Aldrich, J. M., L. D. Muller, and G. A. Varga. 1993. Effect of somatotropin administration and duodenal infusion of methionine and lysine on lactational performance and nutrient flow to the small intestine. Br. J. Nutr. 69:49-58.

Bequette, B. J., J. A. Metcalf, D. Wray-Cahen, F. R. C. Backwell, J. D. Sutton, M. A. Lomax, J. C. Macrae, and G. E. Lobley. 1996. Leucine and protein metabolism in the lactating dairy cow mammary gland: Responses to supplemental dietary crude protein intake. J. Dairy Res. 63:209-222

Bequette, B. J., F. R. C. Backwell, and L. A. Crompton. 1998. Current concepts of amino acid and protein metabolism in the mammary gland of the lactating ruminant. J. Dairy Sci. 81:2540-2559.

Block, R. J., and D. Bolling. 1951. The Amino Acid Composition of Proteins and Foods. 2nd ed. Thomas, Springfield, IL.

Blouin, J. P., J. F. Bernier, C. K. Reynolds, G. E. Lobley, P. Dubreuil, and H. Lapierre. 2002. Effect of supply of metabolizable protein on splanchnic fluxes of nutrients and hormones in lactating dairy cows. J. Dairy Sci. 85:2618-2630.

Bruckental, I., I. Ascarelli, B. Yosif, and E. Alumot. 1991. Effect of duodenal proline infusion on milk production and composition in dairy cows. Anim. Prod. 53:299-303.

Bruckental, I., G. B. Huntington, C. Kirk Baer, and R. A. Erdman. 1997. The effect of abomasal infusion of casein and recombinant somatotropin hormone injection on nitrogen balance and amino acid fluxes in portal-drained viscera and net hepatic and total splanchnic blood in Holstein steers. J. Anim. Sci. 75:1119-1129.

Cant, J. P., E. J. DePeters, and R. L. Baldwin. 1991. Effect of dietary fat and postruminal casein administration on milk composition of lactating dairy cows. J. Dairy Sci. 74:211-219.

Castillo, L., T. E. Chapman, M. Sanchez, Y. Yu, J. F. Burke, A. M. Ajami, J. Vogt, and V. R. Young. 1993. Plasma arginine and citrulline kinetics in adults given adequate and arginine-free diets. Proc. Natl. Acad. Sci. USA 90:7749-7753.

Chamberlain, D. G., and P. C. Thomas. 1982. Effect of intravenous supplements of L-methionine on milk yield and composition in cows given silage-cereal diets. J. Dairy Res. 49:25-28. 
Choung, J., and D. G. Chamberlain. 1992a. Protein nutrition of dairy cows receiving grass silage diets: Effects on silage intake and milk production of postruminal supplements of casein or soyaprotein isolate and the effects of intravenous infusions of a mixture of methionine, phenylalanine, and tryptophan. J. Sci. Food Agric. 58:307-314.

Choung, J., and D. G. Chamberlain. 1992b. Protein nutrition of dairy cows receiving grass silage diets: The effects of post-ruminal supplements of proteins and amino acids. J. Sci. Food Agric. 60:25-30.

Choung, J., and D. G. Chamberlain. 1992c. The effect of the addition of cell-wall degrading enzymes at ensiling on the response to postruminal supplementation of protein in dairy cows receiving a silage-based diet. J. Sci. Food Agric. 60:525-527.

Choung, J., and D. G. Chamberlain. 1993a. The effects of abomasal infusions of casein or soya-bean-protein isolate on the milk production of dairy cows in mid-lactation. Br. J. Nutr. 69:103-115.

Choung, J., and D. G. Chamberlain. 1993b. Effects on milk yield and composition of intra-abomasal infusions of sodium caseinate, an enzymic hydrolysate of casein or soya-protein isolate in dairy cows. J. Dairy Res. 60:133-138.

Choung, J., and D. G. Chamberlain. 1995a. Effects of abomasal infusions of sodium caseinate, a hydrolysate of casein or a corresponding mixture of free amino acids on milk yield and composition in dairy cows. J. Dairy Res. 62:29-37.

Choung, J., and D. G. Chamberlain. 1995b. The effects of intravenous supplements of amino acids on the milk production of dairy cows consuming grass silage and a supplement containing feather meal. J. Sci. Food Agric. 68:265-270.

Choung, J., and D. G. Chamberlain. 1995c. Effects of abomasal infusions of sodium caseinate and of casein hydrolysates varying in the relative proportions of peptides and free amino acids on milk production in dairy cows. J. Dairy Res. 62:423-429.

Clark, J. H. 1975. Lactational responses to postruminal administration of proteins and amino acids. J. Dairy Sci. 58:1178-1197.

Clark, J. H., H. R. Spires, R. G. Derrig, and M. R. Bennink. 1977. Milk production, nitrogen utilization, and glucose synthesis in lactating cows infused postruminally with sodium caseinate and glucose. J. Nutr. 107:631-644.

CNCPS. 2000. The Cornell University Nutrient Management Planning System. The net carbohydrate and protein system for evaluating herd nutrition and nutrient excretion. CNCPS version 4.0, November 3rd, 2000. Model Documentation.

Cohick, W. S., J. L. Vicini, C. R. Staples, J. H. Clark, S. N. McCutcheon, and D. E. Bauman. 1986. Effects of intake and postruminal casein infusion on performance and concentrations of hormones in plasma of lactating cows. J. Dairy Sci. 69:3022-3031.

de Lange, C. F. M., W. C. Sauer, R. Mosenthin, and W. B. Souffrant. 1989a. The effect of feeding different protein-free diets on the recovery and amino acid composition of endogenous protein collected from the distal ileum and feces in pigs. J. Anim. Sci. 67:746-754

de Lange, C. F. M., W. C. Sauer, and W. B. Souffrant. 1989b. The effect of protein status of the pig on the recovery and amino acid composition of endogenous protein in digesta collected from the distal ileum. J. Anim. Sci. 67:755-762.

DePeters, E. J., and J. P. Cant. 1992. Nutritional factors influencing the nitrogen composition of bovine milk: a review. J. Dairy Sci. 75:2043-2070.

Gahl, M. J., T. D. Crenshaw, and N. J. Benevenga. 1994. Diminishing returns in weight, nitrogen, and lysine gain of pigs fed six levels of lysine from three supplemental sources. J. Anim. Sci. 72:3177-3187.

Gahl, M. J., M. D. Finke, T. D. Crenshaw, and N. J. Benevenga. 1996. Efficiency of lysine or threonine retention in growing rats fed diets limiting in either lysine or threonine. J. Nutr. 126:3090-3099.

Grossman, S. I. 1986. Applied Mathematical Analysis. Wadsworth Publishing Company, Belmont, CA.

Griinari, J. M., M. A. McGuire, D. A. Dwyer, D. E. Bauman, and D. L. Palmquist. 1997a. Role of insulin in the regulation of milk fat synthesis in dairy cows. J. Dairy Sci. 80:1076-1084.

Griinari, J. M., M. A. McGuire, D. A. Dwyer, D. E. Bauman, D. M Barbano, and W. A. House. 1997b. The role of insulin in the regulation of milk protein synthesis in dairy cows. J. Dairy Sci. 80:2361-2371.

Guerino, F., G. B. Huntington, and R. A. Erdman. 1991. The net portal and hepatic flux of metabolites and oxygen consumption in growing beef steers given postruminal casein. J. Anim. Sci. 69:387-395.

Guinard, J., H. Rulquin, and R. Verite. 1994. Effect of graded levels of duodenal infusions of casein on mammary uptake in lactating cows. 1. Major nutrients. J. Dairy Sci. 77:2221-2231.

Guinard, J., and H. Rulquin. 1994. Effects of graded amounts of duodenal infusions of lysine on the mammary uptake of major milk precursors in dairy cows. J. Dairy Sci. 77:3565-3576.

Guinard, J., and H. Rulquin. 1995. Effects of graded amounts of duodenal infusions of methionine on the mammary gland uptake of major milk precursors in dairy cows. J. Dairy Sci. 78:21962207.

Hanigan, M. D., J. P. Cant, D. C. Weakley, and J. L. Beckett. 1998. An evaluation of postabsorptive protein and amino acid metabolism in the lactating dairy cow. J. Dairy Sci. 81:3385-3401.

Huhtanen, P. J., H. O. Miettinen, and V. F. J. Toivonen. 1997. Effects of silage fermentation and post-ruminal casein supplementation in lactating dairy cows: 1 . Diet digestion and milk production. J. Sci. Food Agric. 74:450-458.

Jensen, R. G. 1995. Handbook of Milk Composition. R. G. Jensen, ed. Academic Press, Toronto, ON.

Jobson, J. D. 1992 Applied Multivariate Data Analysis. Volume II: Categorical and Multivariate Methods. Springer-Verlag, New York, NY.

Kim, C. H., J. Choung, and D. G. Chamberlain. 1999. Determination of the first-limiting amino acid for milk production in dairy cows consuming a diet of grass silage and a cereal-based supplement containing feather meal. J. Sci. Food Agric. 79:1703-1708.

Kim, C. H., J. Choung, and D. G. Chamberlain. 2000. Variability in the ranking of the three most-limiting amino acids for milk production in dairy cows consuming grass silage and a cerealbased supplement containing feather meal. J. Sci. Food Agric. 80:1386-1392.

King, K. J., W. G. Bergen, C. J. Sniffen, A. L. Grant, D. B. Grieve, V. L. King, and N. K. Ames. 1991. An assessment of absorbable lysine requirements in lactating cows. J. Dairy Sci. 74:2530-2539.

König, B. A., J. D. Oldham, and D. S. Parker. 1984. The effect of abomasal infusion of casein on acetate, palmitate and glucose kinetics in cows during early lactation. Br. J. Nutr. 52:319-328.

Lapierre, H., J. P. Blouin, J. F. Bernier, C. K. Reynolds, P. Dubreuil, and G. E. Lobley. 2002. Effect of diet quality on whole body and splanchnic protein metabolism in lactating dairy cows. J. Dairy Sci. 85:2631-2641.

Lobley, G. E. 2002. Protein turnover-what does it mean for animal production? Pages 1-15 in Amino Acids: Milk, Meat and More. H. Lapierre and D. Ouellet, eds. CSAS - Symposium - SCSA, Québec, QC.

Lobley, G. E., P. J. Weijs, A. Connell, A. G. Calder, D. S. Brown, and E. Milne. 1996. The fate of absorbed and exogenous ammonia as influenced by forage or forage-concentrate diets in growing sheep. Br. J. Nutr. 76: 231-248.

Lynch, G. L., T. H. Klusmeyer, M. R. Cameron, J. H. Clark, and D. R. Nelson. 1991. Effects of somatotropin and duodenal infusion of amino acids on nutrient passage to duodenum and performance of dairy cows. J. Dairy Sci. 74:3117-3127.

Mackle, T. R., D. A. Dwyer, and D. E. Bauman. 1999a. Effects of branched-chain amino acids and sodium caseinate on milk protein concentration and yield from dairy cows. J. Dairy Sci. 82:161-171.

Mackle, T. R., D. A. Dwyer, K. L. Ingvartsen, P. Y. Chouinard, J. M. Lynch, D. M. Barbano, and D. E. Bauman. 1999b. Effects of insulin and amino acids on milk protein concentration and yield from dairy cows. J. Dairy Sci. 82:1512-1524.

Mepham, T. B. 1982. Amino acid utilization by lactating mammary gland. J. Dairy Sci. 65:287-298.

Metcalf, J. A., L. A. Crompton, D. Wray-Cahen, M. A. Lomax, J. D. Sutton, D. E. Beever, J. C. MacRae, B. J. Bequette, F. R. C. Backwell, and G. E. Lobley. 1996. Responses in milk constituents 
to intravascular administration of two mixtures of amino acids to dairy cows. J. Dairy Sci. 79:1425-1429.

National Research Council. 2001. Nutrient Requirements of Dairy Cattle. 7th rev. ed. Natl. Acad. Sci., Washington, DC.

O'Connor, J. D., C. J. Sniffen, D. G. Fox, and W. Chalupa. 1993. A net carbohydrate and protein system for evaluating cattle diets: IV. Predicting amino acid adequacy. J. Anim. Sci. 71:1298-1311.

Ørskov, E. R., D. A. Grubb, and R. N. B. Kay. 1977. Effect of postruminal glucose or protein supplementation on milk yield and composition in Friesian cows in early lactation and negative energy balance. Br. J. Nutr. 38:397-405.

Ørskov, E. R., N. A Macleod, and D. J. Kyle. 1986. Flow of nitrogen from the rumen and abomasum in cattle and sheep given proteinfree nutrients by intragastric infusion. Br. J. Nutr. 56:241-248.

Pisulewski, P. M., H. Rulquin, J. L. Peyraud, and R. Vérité. 1996. Lactational and systemic responses of dairy cows to postruminal infusions of increasing amounts of methionine. J. Dairy Sci. 79:1781-1791.

Reynolds, C. K., D. P. Casper, D. L. Harmon, and C. T. Milton. 1992. Effect of CP and ME intake on visceral nutrient metabolism in beef steers. J. Anim. Sci. 70(Suppl. 1):315. (Abstr.)

Robinson, P. H., W. Chalupa, C. J. Sniffen, W. E. Julien, H. Sato, T. Fujieda, K. Watanabe, and H. Suzuki. 1999. Influence of postruminal supplementation of methionine and lysine, isoleucine, or all three amino acids on intake and chewing behavior, ruminal fermentation, and milk and milk component production. J. Anim. Sci. 77:2781-2792.

Robinson, P. H., W. Chalupa, C. J. Sniffen, W. E. Julien, H. Sato, T. Fujeda, T. Ueda, and H. Suzuki. 2000. Influence of abomasal infusion of high levels of lysine or methionine, or both, on ruminal fermentation, eating behavior, and performance of lactating dairy cows. J. Anim. Sci. 78:1067-1077.

Rogers, J. A., J. H. Clark, T. R. Drendel, and G. C. Fahey, Jr. 1984. Milk production and nitrogen utilization by dairy cows infused postruminally with sodium caseinate, soybean meal, or cottonseed meal. J. Dairy Sci. 67:1928-1935.

Rohr, K., and P. Lebzien. 1991. Present knowledge of amino acid requirements for maintenance and production. Proc. of the 6th Int. Symp. on Protein Metabolism and Nutrition. Herning, Denmark.

Rulquin, H., P. M. Pisulewski, R. Vérité, and J. Guinard. 1993. Milk production and composition as a function of postruminal lysine and methionine supply: A nutrient-response approach. Livest. Prod. Sci. 37:69-90.

Rulquin, H., and P. M. Pisulewski. 2000a. Effects of duodenal infusion of graded amounts of Leu on mammary uptake and metabolism in dairy cows. J. Dairy Sci. 83(Suppl. 1):164. (Abstr.)

Rulquin, H., and P. M. Pisulewski. 2000b. Effects of duodenal infusion of graded amounts of His on mammary uptake and metabolism in dairy cows. J. Dairy Sci. 83(Suppl. 1):164. (Abstr.)
Rulquin, H., and P. M. Pisulewski. 2000c. Effects of duodenal infusion of graded amounts of Phe on mammary uptake and metabolism in dairy cows. J. Dairy Sci. 83(Suppl. 1):267. (Abstr.)

Rulquin, H., R. Vérité, J. Guinard-Flament, and P. M. Pisulewski. 2001. Acides amines digestibles dans l'intestin. Origines des variations chez les ruminants et répercussions sur les protéines du lait. INRA Prod. Anim. 14:201-210.

Santos, F. A. P., J. E. P. Santos, C. B. Theurer, and J. T. Huber. 1998. Effects of rumen-undegradable protein on dairy cow performance: A 12-year literature review. J. Dairy Sci. 81:3182-3213.

SAS. 1999. SAS/STAT and SAS/ETS User's Guides, Version 8. SAS Institute Inc., Cary, NC.

Schwab, C. G., L. D. Satter, and A. B. Clay. 1976. Response of lactating dairy cows to abomasal infusion of amino acids. J. Dairy Sci. 59:1254-1270.

Schwab, C. G., C. K. Bozak, N. L. Whitehouse, and M. M. A. Mesbah. 1992a. Amino acid limitation and flow to duodenum at four stages of lactation. 1. Sequence of lysine and methionine limitation. J. Dairy Sci. 75:3486-3502.

Schwab, C. G., C. K. Bozak, N. L. Whitehouse, and V. M. Olson. 1992b. Amino acid limitation and flow to the duodenum at four stages of lactation: 2. Extent of lysine limitation. J. Dairy Sci. 75:3503-3518.

Seal, C. J., and C. K. Reynolds. 1993. Nutritional implications of gastrointestinal and liver metabolism in ruminants. Nutr. Res. Rev. 6:185-208.

Seymour, W. M., C. E. Polan, and J. H. Herbein. 1990. Effects of dietary protein degradability and casein or amino acid infusions on production and plasma amino acids in dairy cows. J. Dairy Sci. 73:735-748.

Stein, H. H., N. L. Trottier, C. Bellaver, and R. A. Easter. 1999. The effect of feeding level and physiological status on total flow and amino acid composition of endogenous protein at the distal ileum in swine. J. Anim. Sci. 77:1180-1187.

St-Pierre, N. R. 2001. Invited review: Integrating quantitative findings from multiple studies using mixed model methodology. J. Dairy Sci. 84:741-755.

Vanhatalo, A., P. Huhtanen, V. Toivonen, and T. Varvikko. 1999. Response of dairy cows fed grass silage diets to abomasal infusion of histidine alone or in combinations with methionine and lysine. J. Dairy Sci. 82:2674-2685.

Varvikko, T., A. Vanhatalo, and P. Huhtanen. 1999. Lactation and metabolic responses to graded abomasal doses of methionine and lysine in cows fed grass silage diets. J. Dairy Sci. 82:2659-2673.

Vicini, J. L., J. H. Clark, W. L. Hurley, and J. M. Bahr. 1988. Effects of abomasal or intravenous administration of arginine on milk production, milk composition, and concentrations of somatotropin and insulin in plasma of dairy cows. J. Dairy Sci. 71:658-665.

Whitelaw, F. G., J. S. Milne, E. R. Orskov, and J. S. Smith. 1986. The nitrogen and energy metabolism of lactating cows given abomasal infusions of casein. Br. J. Nutr. 55:537-556.

Williams, A. P. 1978. The amino acid, collagen and mineral composition of preruminant calves. J. Agric. Sci. Camb. 90:617-624. 


\begin{tabular}{|c|c|c|c|c|c|c|c|c|}
\hline $\operatorname{Diet}^{1}$ & $\begin{array}{l}\text { CP in } \\
\text { Diet } \\
(\% \text { DM })\end{array}$ & DIM $^{2}$ & $\begin{array}{l}\mathrm{DMI} \\
(\mathrm{kg} / \mathrm{d})\end{array}$ & $\begin{array}{l}\text { Infusate/rate }{ }^{3} \\
(\mathrm{~g} / \mathrm{d})\end{array}$ & $\begin{array}{l}\text { Infusion } \\
\text { Site }\end{array}$ & $\begin{array}{l}\text { Milk } \\
\text { yield } \\
(\mathrm{kg} / \mathrm{d})\end{array}$ & $\begin{array}{l}\text { True } \\
\text { protein } \\
\text { yield }^{5} \\
(\mathrm{~g} / \mathrm{d})\end{array}$ & Reference \\
\hline \multirow[t]{2}{*}{ GS, Barley } & 14.5 & 137 & $\begin{array}{l}16.2 \\
16.7\end{array}$ & $\overline{\mathrm{TAA}} / 400$ & JV & $\begin{array}{l}23.8 \\
24.4\end{array}$ & $\begin{array}{l}771^{*} \\
854^{*}\end{array}$ & Metcalf et al., 1996 \\
\hline & & & $\begin{array}{l}16.2 \\
16.7\end{array}$ & $\overline{\mathrm{EAA}} / 208$ & & $\begin{array}{l}22.4 \\
23.5\end{array}$ & $\begin{array}{l}728^{*} \\
867^{*}\end{array}$ & \\
\hline AH, Corn, SBM & 16.5 & 220 & $\begin{array}{l}26.2 \\
27.6\end{array}$ & $\overline{\mathrm{CAS}} / 500+\mathrm{BCAA} / 88$ & $\mathrm{AB}$ & $\begin{array}{l}26.5 \\
27.6\end{array}$ & $\begin{array}{l}832 \\
875\end{array}$ & Mackle et al., 1999b \\
\hline GS, Barley, SBM & 14.6 & 123 & $\begin{array}{l}13.9 \\
14.2 \\
14.4 \\
14.4 \\
13.9 \\
14.1 \\
14.2\end{array}$ & $\begin{array}{l}\overline{\mathrm{CAS}} / 100 \\
\mathrm{CAS} / 200 \\
\mathrm{CAS} / 400 \\
\mathrm{CH} / 110 \\
\mathrm{CH} / 220 \\
\mathrm{CH} / 440\end{array}$ & $\mathrm{AB}$ & \begin{tabular}{l|l|}
17.7 & \\
17.9 & \\
18.8 & \\
19.5 & \\
17.7 & \\
17.0 & \\
18.6 &
\end{tabular} & $\begin{array}{l}516 \\
538 \\
588 \\
609 \\
520 \\
534 \\
587\end{array}$ & Choung and Chamberlain, 1995a \\
\hline GS, Barley, SBM & 16.6 & 123 & $\begin{array}{l}13.6 \\
14.2 \\
13.4 \\
13.7 \\
13.6\end{array}$ & $\begin{array}{l}\overline{\mathrm{CAS}} / 160 \\
\mathrm{CAS} / 320 \\
\mathrm{TAA} / 146 \\
\mathrm{TAA} / 292\end{array}$ & $\mathrm{AB}$ & $\begin{array}{l}18.2 \\
19.5 \\
20.3 \\
18.8 \\
20.2\end{array}$ & $\begin{array}{l}510 \\
570 \\
618 \\
535 \\
615\end{array}$ & Choung and Chamberlain, 1995a \\
\hline GS, Barley, FM & 19.3 & 74 & $\begin{array}{l}13.8 \\
14.1 \\
13.6\end{array}$ & $\begin{array}{l}\overline{-} \text { His/9.7, Met/9.1,Lys/30, Trp/2.6 } \\
\text { His/9.7, Met/9.1,Lys/30, Trp/2.6 }\end{array}$ & JV & $\begin{array}{l}17.4 \\
20.0 \\
18.6\end{array}$ & $\begin{array}{l}487 \\
615 \\
541\end{array}$ & Choung and Chamberlain, 1995b \\
\hline GS, Barley, FM & 17.3 & 74 & $\begin{array}{l}13.6 \\
13.7 \\
14.0\end{array}$ & 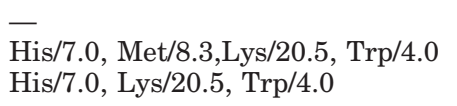 & JV & $\begin{array}{l}17.1 \\
18.8 \\
19.3\end{array}$ & $\begin{array}{l}424 \\
503 \\
499\end{array}$ & Choung and Chamberlain, 1995b \\
\hline TS, CS, Corn & 14.4 & 207 & $\begin{array}{l}23.8 \\
23.1 \\
21.9 \\
22.0\end{array}$ & $\begin{array}{l}- \\
\text { Lys/50 } \\
\text { Met/15.9 } \\
\text { Lys/49.4, Met/16.2 }\end{array}$ & $\mathrm{AB}$ & $\begin{array}{l}36.9 \\
35.8 \\
34.2 \\
34.5\end{array}$ & $\begin{array}{l}1107 \\
1051 \\
1042 \\
1042\end{array}$ & Robinson et al., 2000 \\
\hline TS, CS, barley & 14.6 & 50 & $\begin{array}{l}21.4 \\
21.3\end{array}$ & $\overline{\text { Ile }} / 30.7$ & $\mathrm{AB}$ & $\begin{array}{l}33.6 \\
35.1\end{array}$ & $\begin{array}{l}902 \\
921\end{array}$ & Robinson et al., 1999 \\
\hline GS, barley & 14.1 & 140 & $\begin{array}{l}13.6 \\
13.7 \\
13.7 \\
14.3\end{array}$ & $\begin{array}{l}- \\
\text { CAS/110 } \\
\text { CAS/220 } \\
\text { CAS/330 }\end{array}$ & $\mathrm{AB}$ & $\begin{array}{l}13.9 \\
15.7 \\
17.1 \\
17.4\end{array}$ & $\begin{array}{l}408 \\
436 \\
510 \\
557\end{array}$ & Choung and Chamberlain, 1993a \\
\hline CS, corn, SBM & 14.3 & 133 & $\begin{array}{l}17.9 \\
17.1 \\
17.2 \\
16.8\end{array}$ & $\begin{array}{l}-\overline{C A S} / 400 \\
\text { CH/400 } \\
\text { Lys/30.1, Met/11.3 }\end{array}$ & $\mathrm{AB}$ & $\begin{array}{l}23.3 \\
24.4 \\
23.6 \\
22.9\end{array}$ & $\begin{array}{l}698 \\
744 \\
698 \\
707\end{array}$ & Seymour et al., 1990 \\
\hline CS, corn, SBM,CGM & 14.3 & 133 & $\begin{array}{l}17.1 \\
17.2 \\
17.4 \\
16.8\end{array}$ & $\begin{array}{l}\overline{-} \\
\text { CAS/400 } \\
\text { CH/400 } \\
\text { Lys/30.1, Met/11.3 }\end{array}$ & $\mathrm{AB}$ & $\begin{array}{l}23.4 \\
24.6 \\
24.3 \\
23.5\end{array}$ & $\begin{array}{l}670 \\
716 \\
716 \\
688\end{array}$ & Seymour et al., 1990 \\
\hline
\end{tabular}


Appendix A Continued. Description of publications used to generate the database.

\begin{tabular}{|c|c|c|c|c|c|c|c|c|}
\hline $\operatorname{Diet}^{1}$ & $\begin{array}{l}\text { CP in } \\
\text { Diet } \\
(\% \text { DM) }\end{array}$ & $\mathrm{DIM}^{2}$ & $\begin{array}{l}\mathrm{DMI} \\
(\mathrm{kg} / \mathrm{d})\end{array}$ & $\begin{array}{l}\text { Infusate/rate } \\
(\mathrm{g} / \mathrm{d})\end{array}$ & $\begin{array}{l}\text { Infusion }{ }^{4} \\
\text { Site }\end{array}$ & $\begin{array}{l}\text { Milk } \\
\text { yield } \\
(\mathrm{kg} / \mathrm{d})\end{array}$ & $\begin{array}{l}\text { True } \\
\text { protein } \\
\text { yield }^{5} \\
\text { (g/d) }\end{array}$ & Reference \\
\hline CS, GNM, SBM & 16.3 & 89 & $\begin{array}{l}15.3 \\
15.3 \\
15.2 \\
15.3\end{array}$ & $\begin{array}{l}- \\
\text { CAS/177 } \\
\text { CAS/352 } \\
\text { CAS/762 }\end{array}$ & DU & $\begin{array}{l}24.1 \\
25.5 \\
25.3 \\
26.7\end{array}$ & $\begin{array}{l}660^{*} \\
717^{*} \\
718^{*} \\
786^{*}\end{array}$ & Guinard et al., 1994 \\
\hline AH, Corn, SBM & 16.6 & 184 & $\begin{array}{l}20.0 \\
19.6\end{array}$ & $\overline{\mathrm{CAS}} / 500$ & $\mathrm{AB}$ & $\begin{array}{l}26.3 \\
28.6\end{array}$ & $\begin{array}{l}761^{*} \\
831^{*}\end{array}$ & Griinari et al., 1997a, 1997b \\
\hline AH, Corn, SBM & 16.2 & 112 & $\begin{array}{l}24.8 \\
24.3 \\
23.7 \\
24.1\end{array}$ & $\begin{array}{l}-\overline{\mathrm{BCAA}} / 150 \\
\mathrm{CAS} / 600 \\
\mathrm{BCAA} / 44, \mathrm{CAS} / 600\end{array}$ & $\mathrm{AB}$ & $\begin{array}{l}32.3 \\
32.5 \\
33.2 \\
33.4\end{array}$ & $\begin{array}{l}930^{*} \\
920^{*} \\
976^{*} \\
979^{*}\end{array}$ & Mackle et al., 1999a \\
\hline CS, GNM, SBM & 17.8 & 119 & $\begin{array}{l}17.0 \\
17.1 \\
17.1 \\
17.0\end{array}$ & $\begin{array}{l}- \\
\text { Met/8 } \\
\text { Met/16 } \\
\text { Met/32 }\end{array}$ & DU & $\begin{array}{l}24.2 \\
23.2 \\
24.3 \\
24.0\end{array}$ & $\begin{array}{l}674^{*} \\
660^{*} \\
707^{*} \\
689^{*}\end{array}$ & Guinard and Rulquin, 1995 \\
\hline GS, Barley, SBM & 15.3 & 126 & $\begin{array}{l}13.8 \\
14.4\end{array}$ & $\overline{\mathrm{CAS}} / 230$ & $\mathrm{AB}$ & $\begin{array}{l}20.2 \\
22.4\end{array}$ & $\begin{array}{l}582 \\
674\end{array}$ & Choung and Chamberlain, 1992b \\
\hline CS, AS, Corn & 16.0 & 28 & $\begin{array}{l}20.4 \\
21.4 \\
21.9 \\
20.3\end{array}$ & $\begin{array}{l}\text { Met/12 } \\
\text { Lys/30 } \\
\text { Met/12, Lys/30 } \\
\text { CAS/400 }\end{array}$ & DU & $\begin{array}{l}37.4 \\
39.8 \\
40.0 \\
40.0\end{array}$ & $\begin{array}{r}921 \\
1010 \\
1056 \\
1054\end{array}$ & Schwab et al., 1992a \\
\hline CS, AS, Corn & 16.0 & 70 & $\begin{array}{l}21.1 \\
21.5 \\
21.6 \\
21.9\end{array}$ & $\begin{array}{l}\text { Met/12 } \\
\text { Lys/30 } \\
\text { Met/12, Lys/30 } \\
\text { CAS/400 }\end{array}$ & DU & $\begin{array}{l}35.1 \\
35.6 \\
35.0 \\
37.0\end{array}$ & $\begin{array}{l}877 \\
923 \\
925 \\
980\end{array}$ & Schwab et al., 1992a \\
\hline CS, AS, Corn & 16.0 & 133 & $\begin{array}{l}21.2 \\
21.3 \\
21.9 \\
21.8\end{array}$ & $\begin{array}{l}\text { Met/10 } \\
\text { Lys/25 } \\
\text { Met/10, Lys/25 } \\
\text { CAS/333 }\end{array}$ & DU & $\begin{array}{l}28.8 \\
29.3 \\
29.8 \\
30.9\end{array}$ & $\begin{array}{l}766 \\
777 \\
818 \\
856\end{array}$ & Schwab et al., 1992a \\
\hline CS, AS, Corn & 16.0 & 203 & $\begin{array}{l}18.6 \\
18.4 \\
19.2 \\
17.8\end{array}$ & $\begin{array}{l}\text { Met/8 } \\
\text { Lys/20 } \\
\text { Met/8, Lys/20 } \\
\text { CAS/266 }\end{array}$ & DU & $\begin{array}{l}21.1 \\
20.9 \\
21.2 \\
20.8\end{array}$ & $\begin{array}{l}584 \\
584 \\
617 \\
588\end{array}$ & Schwab et al., 1992a \\
\hline CS, AS, Corn & 17.3 & 28 & $\begin{array}{l}17.3 \\
17.8 \\
18.8 \\
18.8\end{array}$ & $\begin{array}{l}-\overline{M e t} / 10, \text { Lys/10 } \\
\text { Met/10, Lys/20 } \\
\text { Met/10, Lys/30 }\end{array}$ & DU & $\begin{array}{l}31.7 \\
32.2 \\
34.7 \\
35.5\end{array}$ & $\begin{array}{l}781 \\
908 \\
966 \\
995\end{array}$ & Schwab et al., $1992 b$ \\
\hline CS, AS, Corn & 14.3 & 105 & $\begin{array}{l}20.4 \\
20.3 \\
21.5 \\
20.8\end{array}$ & $\begin{array}{l}-\overline{M e t} / 10, \text { Lys/10 } \\
\text { Met/10, Lys/20 } \\
\text { Met/10, Lys/30 }\end{array}$ & DU & $\begin{array}{l}32.5 \\
32.4 \\
33.1 \\
32.8\end{array}$ & $\begin{array}{l}853 \\
870 \\
910 \\
894\end{array}$ & Schwab et al., $1992 b$ \\
\hline CS, AS, Corn & 14.6 & 154 & $\begin{array}{l}20.7 \\
20.4 \\
20.9 \\
20.6\end{array}$ & $\begin{array}{l}\bar{M} \\
\text { Met/10, Lys/10, Lys/20 } \\
\text { Met/10, Lys/30 }\end{array}$ & DU & $\begin{array}{l}30.4 \\
31.4 \\
30.4 \\
30.7\end{array}$ & $\begin{array}{l}836 \\
886 \\
880 \\
895\end{array}$ & Schwab et al., $1992 b$ \\
\hline
\end{tabular}




\begin{tabular}{|c|c|c|c|c|c|c|c|c|}
\hline Diet $^{1}$ & $\begin{array}{l}\text { CP in } \\
\text { Diet } \\
(\% \text { DM })\end{array}$ & $\mathrm{DIM}^{2}$ & $\begin{array}{l}\mathrm{DMI} \\
(\mathrm{kg} / \mathrm{d})\end{array}$ & $\begin{array}{l}\text { Infusate/rate }{ }^{3} \\
(\mathrm{~g} / \mathrm{d})\end{array}$ & $\begin{array}{l}\text { Infusion }{ }^{4} \\
\text { Site }\end{array}$ & $\begin{array}{l}\text { Milk } \\
\text { yield } \\
(\mathrm{kg} / \mathrm{d})\end{array}$ & $\begin{array}{l}\text { True } \\
\text { protein } \\
\text { yield }^{5} \\
(\mathrm{~g} / \mathrm{d})\end{array}$ & Reference \\
\hline CS, AS, Corn & 14.8 & 210 & $\begin{array}{l}18.7 \\
18.2 \\
19.3 \\
18.5\end{array}$ & $\begin{array}{l}-\overline{M e t} / 8, \text { Lys/8 } \\
\text { Met/8, Lys/16 } \\
\text { Met/8, Lys/24 }\end{array}$ & DU & $\begin{array}{l}23.0 \\
20.7 \\
22.1 \\
22.1\end{array}$ & $\begin{array}{l}671 \\
622 \\
682 \\
678\end{array}$ & Schwab et al., 1992b \\
\hline GH, WS, Barley & 11.0 & 7 & $\begin{array}{l}14.3 \\
14.3 \\
14.3\end{array}$ & $\begin{array}{l}\overline{\mathrm{CAS}} / 240 \\
\mathrm{CAS} / 460\end{array}$ & $\mathrm{AB}$ & $\begin{array}{l}22.1 \\
23.8 \\
23.5\end{array}$ & $\begin{array}{l}565 \\
648 \\
635\end{array}$ & König et al., 1984 \\
\hline GS, Barley & 14.8 & 88 & $\begin{array}{l}14.1 \\
13.8\end{array}$ & $\begin{array}{l}\mathrm{CAS} / 230 \\
\mathrm{CH} / 260\end{array}$ & $\mathrm{AB}$ & $\begin{array}{l}20.1 \\
20.2\end{array}$ & $\begin{array}{l}563 \\
562\end{array}$ & Choung and Chamberlain, 1993b \\
\hline CS, GH, Corn & 15.2 & 94 & $\begin{array}{l}19.9 \\
19.4\end{array}$ & $\overline{\text { Lys }} / 24$, Met/8 & DU & $\begin{array}{l}29.1 \\
27.9\end{array}$ & $\begin{array}{l}771 \\
744\end{array}$ & Lynch et al., 1991 \\
\hline CS, AHL, Corn & 15.0 & 82 & $\begin{array}{l}18.7 \\
19.0 \\
12.3 \\
12.7\end{array}$ & $\begin{array}{l}\overline{\mathrm{CAS}} / 395 \\
\overline{\mathrm{CAS}} / 395\end{array}$ & $\mathrm{AB}$ & $\begin{array}{l}25.4 \\
27.2 \\
21.5 \\
24.0\end{array}$ & $\begin{array}{l}716 \\
800 \\
577 \\
688\end{array}$ & Cohick et al., 1986 \\
\hline CS, GNM, SBM & 17.7 & 144 & $\begin{array}{l}17.0 \\
16.6 \\
16.7 \\
17.0\end{array}$ & $\begin{array}{l}- \\
\text { Lys } / 9 \\
\text { Lys/27 } \\
\text { Lys } / 63\end{array}$ & $\mathrm{DU}$ & $\begin{array}{l}21.7 \\
22.4 \\
21.8 \\
21.8\end{array}$ & $\begin{array}{l}670^{*} \\
702^{*} \\
698^{*} \\
683^{*}\end{array}$ & Guinard and Rulquin, 1994 \\
\hline CS, SBM, Corn & 17.6 & 35 & $\begin{array}{l}23.0 \\
22.2 \\
22.6 \\
23.1 \\
22.9\end{array}$ & $\begin{array}{l}\overline{\text { Met}} / 6 \\
\text { Met/12 } \\
\text { Met/18 } \\
\text { Met/24 }\end{array}$ & $\mathrm{DU}$ & $\begin{array}{l}37.5 \\
37.9 \\
36.3 \\
36.6 \\
37.1\end{array}$ & $\begin{array}{l}1020^{*} \\
1046^{*} \\
1038^{*} \\
1076^{*} \\
1102^{*}\end{array}$ & Pisulewski et al., 1996 \\
\hline CS, Corn, SBM & 16.8 & 61 & $\begin{array}{l}20.0 \\
19.8\end{array}$ & $\overline{\text { Lys/24, Met/8 }}$ & $\mathrm{DU}$ & $\begin{array}{l}31.5 \\
32.8\end{array}$ & $\begin{array}{l}856 \\
893\end{array}$ & Aldrich et al., 1993 \\
\hline AH, Barley, Corn & $\begin{array}{l}14.9 \\
15.9\end{array}$ & 102 & $\begin{array}{l}16.9 \\
17.4\end{array}$ & $\begin{array}{l}\text { CAS } / 400 \\
\text { CAS } / 400\end{array}$ & $\mathrm{AB}$ & $\begin{array}{l}23.9 \\
27.0\end{array}$ & $\begin{array}{l}718 \\
753\end{array}$ & Cant et al., 1991 \\
\hline GS, Barley, Oats & 14.2 & 110 & $\begin{array}{l}19.1 \\
19.0 \\
19.6 \\
19.8 \\
19.2\end{array}$ & $\begin{array}{l}\overline{\text { Met}} / 10 \\
\text { Met/20 } \\
\text { Met/30 } \\
\text { Met/40 }\end{array}$ & $\mathrm{AB}$ & $\begin{array}{l}24.9 \\
24.7 \\
25.3 \\
25.6 \\
25.3\end{array}$ & $\begin{array}{l}743^{*} \\
732^{*} \\
763^{*} \\
768^{*} \\
759^{*}\end{array}$ & Varvikko et al., 1999 \\
\hline GS, Barley, Oats & 13.5 & 196 & $\begin{array}{l}17.4 \\
17.8 \\
17.8 \\
17.7 \\
17.6\end{array}$ & $\begin{array}{l}- \\
\text { Lys } / 15 \\
\text { Lys/30 } \\
\text { Lys/45 } \\
\text { Lys/60 }\end{array}$ & $\mathrm{AB}$ & $\begin{array}{l}22.0 \\
22.1 \\
22.2 \\
21.9 \\
22.0\end{array}$ & $\begin{array}{l}663^{*} \\
672^{*} \\
670^{*} \\
665^{*} \\
654^{*}\end{array}$ & Varvikko et al., 1999 \\
\hline GS, Barley, Oats & 13.4 & 105 & $\begin{array}{l}16.1 \\
16.3 \\
16.3 \\
16.2 \\
16.4\end{array}$ & $\begin{array}{l}\text { - } \\
\text { His/6.5 } \\
\text { His/6.5, Met/6 } \\
\text { His/6.5, Lys/19 } \\
\text { His/6.5, Met/6, Lys/19 }\end{array}$ & $\mathrm{AB}$ & $\begin{array}{l}22.9 \\
23.6 \\
23.7 \\
24.2 \\
23.7\end{array}$ & $\begin{array}{l}646 \\
671 \\
677 \\
667 \\
678\end{array}$ & Vanhatalo et al., 1999 \\
\hline
\end{tabular}


Appendix A Continued. Description of publications used to generate the database.

\begin{tabular}{|c|c|c|c|c|c|c|c|c|}
\hline Diet $^{1}$ & $\begin{array}{l}\text { CP in } \\
\text { Diet } \\
(\% \text { DM })\end{array}$ & $\mathrm{DIM}^{2}$ & $\begin{array}{l}\mathrm{DMI} \\
(\mathrm{kg} / \mathrm{d})\end{array}$ & $\begin{array}{l}\text { Infusate/rate }{ }^{3} \\
\text { (g/d) }\end{array}$ & $\begin{array}{l}\text { Infusion }{ }^{4} \\
\text { Site }\end{array}$ & $\begin{array}{l}\text { Milk } \\
\text { yield } \\
(\mathrm{kg} / \mathrm{d})\end{array}$ & $\begin{array}{l}\text { True } \\
\text { protein } \\
\text { yield }^{5} \\
(\mathrm{~g} / \mathrm{d})\end{array}$ & Reference \\
\hline CS, Corn, CGM & 15.7 & 49 & $\begin{array}{l}19.2 \\
19.2 \\
19.5\end{array}$ & $\begin{array}{l}-\overline{L y s} / 45 \\
\text { Lys/90 }\end{array}$ & $\mathrm{AB}$ & $\begin{array}{l}26.4 \\
27.4 \\
27.7\end{array}$ & $\begin{array}{l}763 \\
818 \\
884\end{array}$ & King et al., 1991 \\
\hline CS, Corn, CGM & 15.7 & 35 & $\begin{array}{l}23.1 \\
22.7 \\
23.0 \\
22.7 \\
22.7\end{array}$ & $\begin{array}{l}- \\
\text { Lys/22.5 } \\
\text { Lys } / 45 \\
\text { Lys/90 } \\
\text { Lys } / 180\end{array}$ & $\mathrm{AB}$ & $\begin{array}{l}29.7 \\
31.2 \\
30.1 \\
31.2 \\
32.1\end{array}$ & $\begin{array}{l}874 \\
939 \\
911 \\
949 \\
967\end{array}$ & King et al., 1991 \\
\hline GS, Barley & 13.7 & 98 & $\begin{array}{l}12.2 \\
11.6\end{array}$ & $\overline{\mathrm{M}} \mathrm{et} / 8$ & JV & $\begin{array}{l}15.9 \\
15.7\end{array}$ & $\begin{array}{l}447 \\
426\end{array}$ & Chamberlain and Thomas, 1982 \\
\hline GS, Barley, SBM & 14.7 & 182 & $\begin{array}{l}14.3 \\
14.9\end{array}$ & $\overline{\mathrm{CAS}} / 230$ & $\mathrm{AB}$ & $\begin{array}{l}16.9 \\
19.5\end{array}$ & $\begin{array}{l}498 \\
581\end{array}$ & Choung and Chamberlain, 1992a \\
\hline GS, Barley, SBM & $\begin{array}{l}14.6 \\
18.7\end{array}$ & 56 & $\begin{array}{l}15.4 \\
15.1 \\
16.0\end{array}$ & $\begin{array}{l}\overline{\text { Met/5, Phe/9.1, Trp/2.2 }} \\
-\end{array}$ & JV & $\begin{array}{l}22.4 \\
21.9 \\
23.0\end{array}$ & $\begin{array}{l}620 \\
616 \\
671\end{array}$ & Choung and Chamberlain, 1992a \\
\hline GS, Barley, SBM & $\begin{array}{l}14.6 \\
18.7\end{array}$ & 56 & $\begin{array}{l}15.4 \\
15.1 \\
16.0 \\
15.7\end{array}$ & $\begin{array}{l}\bar{M} \text { Met/5, Phe/9.1, Trp/2.2 } \\
\overline{\text { Met/5, Phe/9.1, Trp/2.2 }}\end{array}$ & JV & $\begin{array}{l}22.4 \\
21.9 \\
23.0 \\
23.0\end{array}$ & $\begin{array}{l}620 \\
616 \\
671 \\
664\end{array}$ & Choung and Chamberlain, 1992a \\
\hline $\mathrm{BS}, \mathrm{BP}$ & 13.6 & 20 & $\begin{array}{l}9.1 \\
9.4 \\
9.7 \\
9.7\end{array}$ & $\begin{array}{l}\overline{\mathrm{CAS}} / 200 \\
\mathrm{CAS} / 400 \\
\mathrm{CAS} / 600\end{array}$ & $\mathrm{AB}$ & $\begin{array}{l}13.0 \\
15.3 \\
16.5 \\
17.2\end{array}$ & $\begin{array}{l}361 \\
436 \\
479 \\
508\end{array}$ & Whitelaw et al., 1986 \\
\hline AH, Corn & 18.0 & - & $\begin{array}{l}20.5 \\
20.4\end{array}$ & $\overline{\mathrm{CAS}} / 462$ & $\mathrm{AB}$ & $\begin{array}{l}30.6 \\
32.7\end{array}$ & $\begin{array}{r}970 \\
1066\end{array}$ & Rogers et al., 1984 \\
\hline GS, Barley, FM & 20.0 & 154 & $\begin{array}{l}17.8 \\
16.9 \\
17.3 \\
16.9\end{array}$ & $\begin{array}{l}\text { EAA/114.4 } \\
\text { His/6, Met/7.1, Lys/17.6 } \\
\text { His/6 }\end{array}$ & JV & $\begin{array}{l}14.2 \\
17.1 \\
16.6 \\
16.5\end{array}$ & $\begin{array}{l}482 \\
581 \\
582 \\
538\end{array}$ & Kim et al., 2000 \\
\hline GS, Barley, FM & 21.2 & 39 & $\begin{array}{l}18.1 \\
18.2 \\
18.6 \\
18.5 \\
19.1\end{array}$ & $\begin{array}{l}\text { His/9, Met/10, Lys/25.5, Trp/4.8 } \\
\text { His/9, Lys/25.5, Trp/4.8 } \\
\text { His/9, Met/10, Trp/4.8 } \\
\text { His/9, Met/10, Lys/25.5 }\end{array}$ & JV & $\begin{array}{l}27.0 \\
27.8 \\
27.5 \\
27.2 \\
28.6\end{array}$ & $\begin{array}{l}717 \\
811 \\
729 \\
755 \\
834\end{array}$ & Kim et al., 2000 \\
\hline GS, Barley, FM & 21.1 & 42 & $\begin{array}{l}16.4 \\
16.7 \\
16.1 \\
16.7\end{array}$ & $\begin{array}{l}-\overline{H i s} / 9.7, \mathrm{Met} / 9.1, \mathrm{Lys} / 30, \operatorname{Trp} / 2.6 \\
\text { Met/9.1, Lys/30, Trp/2.6 } \\
\text { His/9.7, Met/9.1, Trp/2.6 }\end{array}$ & JV & $\begin{array}{l}25.9 \\
28.4 \\
25.2 \\
28.0\end{array}$ & $\begin{array}{l}688 \\
813 \\
665 \\
791\end{array}$ & Kim et al., 1999 \\
\hline GS, Barley, SBM & 14.7 & 70 & $\begin{array}{l}14.2 \\
14.9\end{array}$ & $\overline{\mathrm{CAS}} / 230$ & $\mathrm{AB}$ & $\begin{array}{l}14.4 \\
16.6\end{array}$ & $\begin{array}{l}432 \\
519\end{array}$ & Choung and Chamberlain, 1992c \\
\hline GS, Barley & 13.7 & 56 & $\begin{array}{l}18.4 \\
17.4 \\
17.9 \\
17.9\end{array}$ & $\begin{array}{l}\overline{\mathrm{CAS}} / 400 \\
\overline{\mathrm{CAS}} / 400\end{array}$ & DU & $\begin{array}{l}25.2 \\
24.9 \\
27.4 \\
26.7\end{array}$ & $\begin{array}{l}769 \\
734 \\
854 \\
829\end{array}$ & Huhtanen et al., 1997 \\
\hline
\end{tabular}




\begin{tabular}{|c|c|c|c|c|c|c|c|c|}
\hline $\operatorname{Diet}^{1}$ & $\begin{array}{l}\text { CP in } \\
\text { Diet } \\
(\% \text { DM })\end{array}$ & $\mathrm{DIM}^{2}$ & $\begin{array}{l}\mathrm{DMI} \\
(\mathrm{kg} / \mathrm{d})\end{array}$ & $\begin{array}{l}\text { Infusate/rate }{ }^{3} \\
(\mathrm{~g} / \mathrm{d})\end{array}$ & $\begin{array}{l}\text { Infusion }{ }^{4} \\
\text { Site }\end{array}$ & $\begin{array}{l}\text { Milk } \\
\text { yield } \\
(\mathrm{kg} / \mathrm{d})\end{array}$ & $\begin{array}{l}\text { True } \\
\text { protein } \\
\text { yield } \\
\text { (g/d) }\end{array}$ & Reference \\
\hline BS, Barley & 13.1 & 7 & $\begin{array}{l}11.2 \\
11.0\end{array}$ & $\overline{\mathrm{CAS}} / 300$ & $\mathrm{AB}$ & $\begin{array}{l}16.8 \\
19.5\end{array}$ & $\begin{array}{l}476 \\
601\end{array}$ & Ørskov et al., 1977 \\
\hline GH, Corn & 11.5 & 70 & $\begin{array}{l}16.3 \\
17.2 \\
17.0 \\
17.4 \\
18.3 \\
17.7 \\
18.1 \\
17.7\end{array}$ & $\begin{array}{l}\overline{\text { Met/7.1 }} \\
\text { Met/7.1, Lys/22.1 } \\
\text { Met/7.1, Lys/22.1, Val/18.1 } \\
\text { Met/7.1, Lys/22.1, Val/18.1, Ile/16.1 } \\
\text { EAA/97.3 } \\
\text { EAA/123.3 } \\
\text { EAA/136.6 }\end{array}$ & $\mathrm{AB}$ & $\begin{array}{l}23.3 \\
23.0 \\
23.0 \\
23.6 \\
23.8 \\
23.9 \\
24.9 \\
24.6\end{array}$ & $\begin{array}{l}616 \\
604 \\
640 \\
646 \\
669 \\
655 \\
697 \\
696\end{array}$ & Schwab et al., 1976 \\
\hline GH, Corn & 10.7 & 70 & $\begin{array}{l}17.9 \\
16.9 \\
17.6 \\
17.7\end{array}$ & $\begin{array}{l}- \\
\text { EAA/119.8 } \\
\text { EAA/164.8 } \\
\text { CAS/425 }\end{array}$ & $\mathrm{AB}$ & $\begin{array}{l}29.1 \\
29.8 \\
29.4 \\
30.8\end{array}$ & $\begin{array}{l}738 \\
793 \\
815 \\
830\end{array}$ & Schwab et al., 1976 \\
\hline CS, Corn & 10.7 & 70 & $\begin{array}{l}19.1 \\
19.3 \\
19.2 \\
19.3 \\
19.4\end{array}$ & $\begin{array}{l}- \\
\text { Lys/27.8, Met/11.3 } \\
\text { Lys/27.8, Met/11.3, Val/25 } \\
\text { Lys/27.8, Met/11.3, Val/25, Phe/19.6, Ile/22.3 } \\
\text { CAS/425 }\end{array}$ & $\mathrm{AB}$ & $\begin{array}{l}27.2 \\
27.1 \\
26.4 \\
27.0 \\
27.7\end{array}$ & $\begin{array}{l}708 \\
747 \\
741 \\
751 \\
777\end{array}$ & Schwab et al., 1976 \\
\hline CS, Corn & 10.9 & 70 & $\begin{array}{l}20.5 \\
20.5 \\
20.2 \\
19.9 \\
20.5\end{array}$ & $\begin{array}{l}- \\
\text { Lys/27.8 } \\
\text { Lys/27.8, Met/11.3 } \\
\text { Lys/27.8, Met/11.3, Val/25 } \\
\text { CAS/425 }\end{array}$ & $\mathrm{AB}$ & $\begin{array}{l}28.4 \\
28.9 \\
29.2 \\
28.7 \\
29.8\end{array}$ & $\begin{array}{l}787 \\
804 \\
829 \\
818 \\
864\end{array}$ & Schwab et al., 1976 \\
\hline CS, Corn & 10.7 & 70 & $\begin{array}{l}18.9 \\
18.3 \\
18.1 \\
19.2 \\
19.1 \\
19.6\end{array}$ & $\begin{array}{l}- \\
\text { Lys/27.8 } \\
\text { Lys/27.8, Met/11.3 } \\
\text { Lys/27.8, Met/11.3, Thr/15.2 } \\
\text { His/10.2, Arg/13.7 } \\
\text { CAS/425 }\end{array}$ & $\mathrm{AB}$ & $\begin{array}{l}29.4 \\
29.7 \\
29.8 \\
31.1 \\
30.7 \\
32.2\end{array}$ & $\begin{array}{l}791 \\
801 \\
829 \\
860 \\
813 \\
910\end{array}$ & Schwab et al., 1976 \\
\hline AGH, Corn & 17.7 & - & $\begin{array}{l}18.5 \\
18.7\end{array}$ & $\overline{\mathrm{CAS}} / 450$ & $\mathrm{AB}$ & $\begin{array}{l}28.8 \\
31.0\end{array}$ & $\begin{array}{l}896 \\
997\end{array}$ & Clark et al., 1977 \\
\hline AGHL, CS, Corn & 15.3 & 80 & $\begin{array}{l}20.5 \\
21.0 \\
20.2\end{array}$ & $\begin{array}{l}\overline{-} \\
\text { Arg/109 } \\
\text { Arg/178 }\end{array}$ & $\begin{array}{l}\text { JV } \\
\mathrm{AB}\end{array}$ & $\begin{array}{l}30.7 \\
31.9 \\
33.4\end{array}$ & $\begin{array}{l}874 \\
846 \\
865\end{array}$ & Vicini et al., 1988 \\
\hline CS, Corn, Barley, SBM & $\begin{array}{l}14.0 \\
14.0\end{array}$ & $\begin{array}{r}34 \\
121\end{array}$ & $\begin{array}{l}13.9 \\
14.5 \\
13.8 \\
14.7\end{array}$ & $\begin{array}{l}\overline{-} \\
\text { Pro/80 } \\
\overline{\text { Pro/80 }}\end{array}$ & $\begin{array}{l}\text { DU } \\
\text { DU }\end{array}$ & $\begin{array}{l}35.0 \\
36.0 \\
23.6 \\
24.9\end{array}$ & $\begin{array}{l}911 \\
920 \\
607 \\
693\end{array}$ & Bruckental et al., 1991 \\
\hline
\end{tabular}


Appendix A Continued. Description of publications used to generate the database.

\begin{tabular}{|c|c|c|c|c|c|c|c|c|}
\hline Diet $^{1}$ & $\begin{array}{l}\text { CP in } \\
\text { Diet } \\
\text { (\% DM) }\end{array}$ & $\mathrm{DIM}^{2}$ & $\begin{array}{l}\mathrm{DMI} \\
(\mathrm{kg} / \mathrm{d})\end{array}$ & $\begin{array}{l}\text { Infusate/rate }{ }^{3} \\
(\mathrm{~g} / \mathrm{d})\end{array}$ & $\begin{array}{l}\text { Infusion }{ }^{4} \\
\text { Site }\end{array}$ & $\begin{array}{l}\text { Milk } \\
\text { yield } \\
(\mathrm{kg} / \mathrm{d})\end{array}$ & $\begin{array}{l}\text { True } \\
\text { protein } \\
\text { yield }^{5} \\
\text { (g/d) }\end{array}$ & Reference \\
\hline GS, Barley, SBM & 13.8 & 210 & $\begin{array}{l}12.7 \\
13.1\end{array}$ & $\overline{\mathrm{CAS}} / 180$ & $\mathrm{AB}$ & $\begin{array}{l}12.1 \\
13.1\end{array}$ & $\begin{array}{l}417^{*} \\
473^{*}\end{array}$ & Choung and Chamberlain, 1995c \\
\hline GS, Barley, FM & 19.0 & 70 & $\begin{array}{l}11.0 \\
11.3\end{array}$ & $\overline{\mathrm{CAS}} / 230$ & $\mathrm{AB}$ & $\begin{array}{l}10.7 \\
13.6\end{array}$ & $\begin{array}{l}318^{*} \\
416^{*}\end{array}$ & Choung and Chamberlain, $1995 \mathrm{c}$ \\
\hline
\end{tabular}

${ }^{1}$ Primary ingredients in ration; $\mathrm{AGH}=$ alfalfa-grass hay, $\mathrm{AGHL}=$ alfalfa-grass haylage, $\mathrm{AH}=$ alfalfa hay, $\mathrm{AHL}=$ alfalfa haylage, $\mathrm{AS}=$ alfalfa silage, $\mathrm{BP}=$ beet pulp, $\mathrm{BS}=$ barley straw, CGM = corn gluten meal, CS = corn silage, FM = feather meal, GH = grass hay, GNM = groundnut meal, GS = grass silage, $\mathrm{SBM}=$ soybean meal, TS = timothy silage, WS = wheat straw.

${ }^{2}$ Days in milk at start of experiment.

${ }^{3} \mathrm{CAS}=$ casein, $\mathrm{CH}=$ casein hydrolysate, $\mathrm{EAA}$ = essential AA, NEAA = nonessential AA, TAA = EAA + NEAA.

${ }^{4} \mathrm{AB}=$ abomasal, $\mathrm{DU}=$ duodenal, $\mathrm{JV}=$ jugular vein.

${ }^{5}$ Calculated as published crude protein yield $\times 0.93$ (NRC, 2001) except where indicated by *.

*Published true protein yield. 